I. Lazareva, Cand. Sci. (Geol.), Associate Professor, E-mail: lazareva@mail.univ.kiev.ua,

S. Shnyukov, Dr. Sci. (Geol.), Associate Professor, E-mail: shnyukov@mail.univ.kiev.ua, A. Aleksieienko, PhD student, E-mail: scr315@gmail.com, L. Gavryliv, PhD student, E-mail: liubomyr.gavryliv@gmail.com Taras Schevchenko National University of Kyiv Institute of Geology, 90 Vasylkivska Str., Kyiv, 03022 Ukraine

\title{
ORE-BEARING METASOMATITES OF PERGA AREA AND KOROSTEN PLUTON GRANITOIDS (UKRAINIAN SHIELD): GENETIC RELATIONS ON THE BASIS OF GEOCHEMICAL MODELLING
}

\begin{abstract}
(Рекомендовано членом редакційної колегії д-ром геол.-мінералог. наук, проф. В.М. Загнітком)
Geochemistry of the most typical ore-bearing (sulfide-rare metal mineralization) metasomatites formation within tectonic zones (Perga area) spatially associated with Precambrian (1.75-1.8 Ga) Korosten anorthosite-rapakivigranite pluton (Ukrainian Shield) was investigated in detail. Major and trace elements behavior during the multistage alteration of predominantly granites was studied. All investigated altered varieties were classified into several geochemical types of alteration which result in formation of corresponding metasomatites during the multistage processes: (1) $\mathrm{Fe}-\mathrm{Mg}-\mathrm{Na}-\mathrm{K}-\mathrm{Zn}, \mathrm{Pb}, \mathrm{Nb}, \mathrm{Rb}, \mathrm{Cs}, \mathrm{Cd}$ (Be, Li, Ta etc.) - apogranites, albitites-I, albite-microcline, microclinealbite, siderophyllite-feldspar and siderophyllite metasomatites; (1a) $\mathrm{Na}-\mathrm{Nb}$, Sn (Ta, Be etc.) - albitites-ll; (2) Si - (Sn, Be, W etc.) apogranites and quartz-muscovite greisens. Metasomatites of the $1^{\text {st }}$ (main) type are widely distributed and contain the most of related economic mineralization. Geochemical data obtained were compared to hypothetical compositions of metasomatites, calculated from predesigned geochemical model of the Korosten pluton granitoid evolution based on fractional crystallization equations. A set of zircon, apatite and monazite solubility equations in silicate melts was used in the model designed to estimate magma crystallization temperature in deep chamber and the level of its saturation in $H_{2}$ O. Dependences $C^{L}=C_{0} f^{p-1}\left(C_{0}=\right.$ element concentration in parent magma, $C^{L}=$ element concentration in residual melt, $f=$ weight fraction of liquid phase in magma chamber, $D=$ bulk distribution coefficient of the element) for $\mathrm{Zn}, \mathrm{Pb}, \mathrm{Nb}, \mathrm{F}$ and $\mathrm{Cl}$ show inverse nature. Their extremum points indicate fvalue when residual melt reaches saturation in water (aqueous fluid separation beginning). This makes it possible to calculate the $K^{F / L}=C^{F} / C^{L}\left(C^{F}\right.$ - element concentration in fluid) values and to estimate the $\mathrm{Zn}, \mathrm{Pb}, \mathrm{Nb}$ concentrations in hypothetical (model) metasomatites. Model (calculated) element concentrations correspond to the composition of natural ore-bearing metasomatites of the Perga area. These results confirm the hypothesis that high-temperature metalbearing fluids, which formed metasomatites, were produced by the Korosten pluton granitoids during their magmatic evolution.

Keywords: metasomatites, granite, trace element, magmatic evolution, fluid separation, fluid/melt distribution coefficient, rock alteration, ore mineralization.
\end{abstract}

\section{Introduction}

Metasomatically altered rocks of various compositions (apogranites, diverse feldspar and siderophyllite metasomatites, greisens) are abundant within tectonic zones spatially associated with Precambrian $(\approx 1.75-1.8 \mathrm{Ga}$ (Ponomarenko et al., 2014)) Korosten anorthosite-rapakivi granite pluton (Ukrainian Shield) (Fig. 1). Multistage alteration of predominantly granites resulted in the formation of complex sulfide-rare metal mineralization. Perga area (Fig. 2) is the largest and the most typical site of these metasomatites with economic ores (Belous, 1994; Metalidi and Nechaev, 1983 etc.). All the metasomatites, both with economic and noneconomic mineralization, show uniform F-Li-Be-Nb-Ta-Zr-ThW-Sn-Mo-Zn-Pb-Cu-Bi-Cd geochemical specialization with rarely high $\mathrm{Au}$ and $\mathrm{Ag}$ concentrations in the varieties formed at the final stages of alteration (Belous, 1994; Nechaev, 1998). Available geological data (Fig. 1 and 2) demonstrate close spatial relations between economic ores, metasomatites and differentiated Korosten pluton granitoids. Recently published geochronological data (Verchogliad, 1995 etc.) indicate the ages of metasomatites formation $~ 1760$ $1752 \mathrm{Ma}$, which demonstrate their almost coeval genesis with the pluton. However, despite Perga area (Bespalko, 1975; Belous, 1994; Velikoslavinsky et al., 1978; Verchogliad, 1995; Vynar and Razumeeva, 1972; Galetsky, 1974; Gurov, et al., 1971; Esipchuk et al., 1993; Kazitsyn and Rudnik, 1968; Kovalenko, 1979; Lazareva, 2015; Nechaev, 1998; Shatskaya and Shpanov, 1977; Sheremet et al., 2011; Sheremet et al., 2014; Shnyukov and Lazareva, 2002; Sherbakov, 2005; Shnyukov et al., 2000; Shnyukov et al., 2018) was thoroughly studied, the problem of absence of complete hypothesis about the source of high-temperature metal-bearing fluids that explains metasomatites formation remains until now. The most appropriate point of view is that such fluids were produced by Korosten pluton granitoids during their magmatic evolution, but this hypothesis has not been finally confirmed by now.

The aim of this paper is to solve following tasks: (1) evaluate the ability of the Korosten pluton granitic magma to be the source of high-temperature metal-bearing fluids responsible for both metasomatic alteration and ore mineralization processes and (2) design geochemical model of ore-bearing metasomatically altered rocks formation using the example of Perga area (Fig. 2), which is abundant with such metasomatites that concentrate most of economic ore mineralization.

2. Geological settings of the Perga metasomatites

Perga area (more than $200 \mathrm{~km}^{2}$ ) is situated (Fig. 1) within the northwestern part of the Korosten anartositerapakivi granite pluton $(\approx 1.8-1.75 \mathrm{Ga})$ which is one of the largest and well-preserved magmatic complexes of the Ukrainian Shield (USh) (Esipchuk et al., 1993; Mytrohyn, 2008; Ponomarenko et al., 2014 etc.). It occupies the northwestern part of the USh and covers an area of approximately $12000 \mathrm{~km}^{2}$. Pluton was formed at the subplatform stage of the USh formation and intrudes predominantly gneisses, amphibolites, plagiomigmatites and granites ( $\approx 1.9-2.1 \mathrm{Ga}$ (Ponomarenko et al., 2014 etc.)). At the present erosional level, it comprises $\approx 75 \%$ granitoids (rapakivi, granite-porphyries, vein granites) and $\approx 25 \%$ basic rocks (anorthosites, gabbronorites, subordinate ultrabasic rocks and microgabbros) (Mytrohyn, 2008 etc.).

Metasomatites and economic ores of Perga area are located within 3 to $10 \mathrm{~km}$ wide and approximately $200 \mathrm{~km}$ long northeast-striking structural corridor consisting of numerous fault zones and limited by the longest ones (Fig. 2), which is situated along the northwestern margin of Korosten pluton (Fig. 1). Corridor structure is a result of intense multistage tectonic activity. Submeridional faults were produced in final tectonic events (Galetsky and Zinchenko, 1971 etc.). 


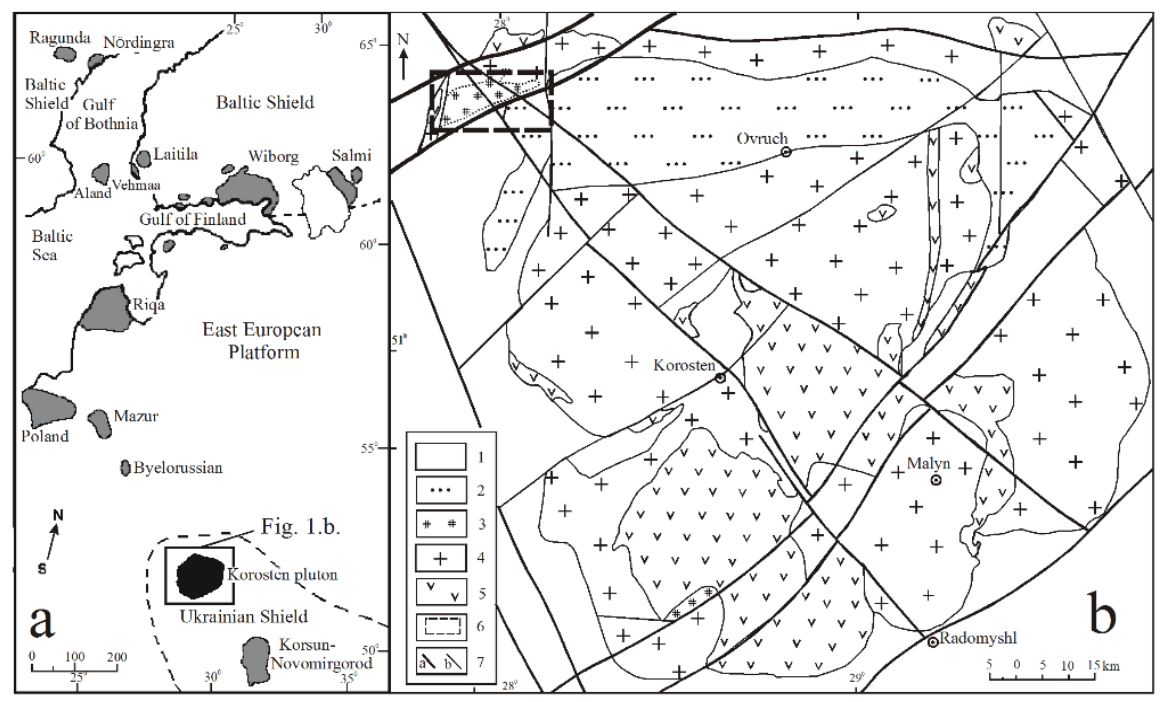

Fig. 1. Geological position of the Perga area.

(a) Position of the Korosten pluton among other anorthosite-rapakivi granite complexes of the East European platform (Velikoslavinsky et al., 1978 etc.). (b) Position of the Perga area within the Korosten pluton region (see references in (Shnyukov et al., 2018)): 1 - host rocks; 2 - platform-type sedimentary-volcanic rocks within the graben structures; 3 - ore-bearing metasomaticaly altered rocks in tectonic zones; 4,5 - Korosten pluton granitoids and basic rocks respectively; 6 - the borders of the region represented on Fig. 2; 7 - faults (a - regional, b - local)

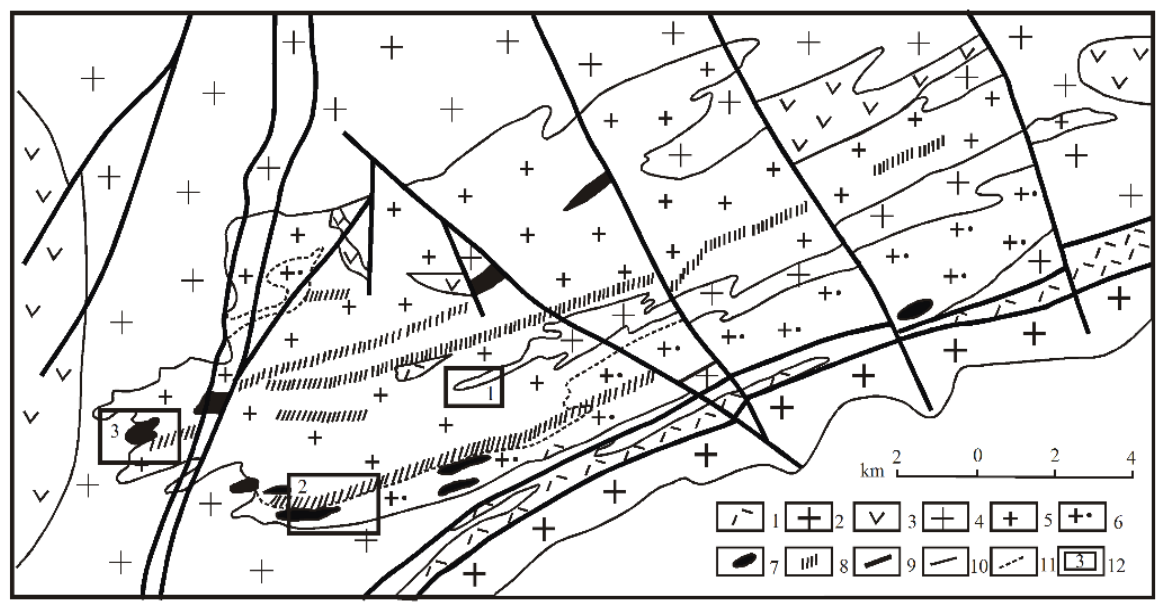

Fig. 2. Geological sketch map of the investigated central part of the Perga area (modified from (Belous, 1994)):

1 - quartz-sericite schists; 2,3 -Korosten pluton granitoids and basic rocks respectively; 4 -metasomaticaly altered granites;

5,6 - ordinary metasomatic granites of Perga type and their varieties with redistributed quartz respectively; 7 - quartz-muscovite greisens;

8 - quartz-feldspar, feldspar, siderophyllite-feldspar; siderophyllite metasomatites of all types (including albitites-I and albitites-II); 9 - faults; 10, 11 - principal and secondary geological boundaries respectively; 12 - regions where metasomaticaly altered granites (1), metasomatites of the $1 \mathrm{st}$ (including albitites-II) (2) and 2nd (3) alteration series were sampled. Points of the unaltered Korosten granites sampling are not shown as they are situated within the central part of the pluton

Metasomatites represented within Perga area inherit tectonic zones. Metasomatic bodies generally have typical vein or more complicated form and also tectonic contacts with the host rocks, which makes it difficult to study formation stages and metasomatic zoning. Host rocks are mainly represented by granitoids with minor gabbroids of the Korosten pluton. Granites play the role of substratum for alteration in most cases.

\section{Sampling and analytical investigations}

Metasomatically altered rocks were sampled within the Perga area (Fig. 2), and subdivided into a number of rock types that are represented in the area. Each rock type was investigated by a series of point geochemical samples $(n=10-30, \sim 300 \mathrm{~g})$ to carry out element analysis as well as detailed mineralogical investigations by some bulk samples (3-5 kg). As a result, metasomatic rock types are represented by a set of more than 200 point and bulk samples collected from drill cores and outcrops.

All samples were crushed, pulverized and analyzed by means of X-ray fluorescence method (XRF). Major oxides and selected trace elements content $\left(\mathrm{SiO}_{2}, \mathrm{TiO}_{2}, \mathrm{Al}_{2} \mathrm{O}_{3}, \mathrm{Fe}_{2} \mathrm{O}_{3}\right.$ total, $\mathrm{MnO}, \mathrm{MgO}, \mathrm{CaO}, \mathrm{Na}_{2} \mathrm{O}, \mathrm{K}_{2} \mathrm{O}, \mathrm{P}_{2} \mathrm{O}_{5}, \mathrm{~S}, \mathrm{Cl}, \mathrm{Zr}, \mathrm{Sr}, \mathrm{Ba}, \mathrm{Rb}, \mathrm{Y}, \mathrm{La}$, $\mathrm{Ce}, \mathrm{Nd}, \mathrm{Nb}, \mathrm{Th}, \mathrm{Ga}, \mathrm{Pb}, \mathrm{Zn}, \mathrm{Cu}$ ) was determined in each sample. The precision and accuracy of the XRF method were verified by replicate analysis of the rock standards of specially prepared reference samples set. Final calculations for each powder sample were obtained as averages of individual powder pellet results with 3-7 for point samples and 10-40 for bulk ones. In the last case total analytical uncertainty (one $\sigma$ level) was estimated as: $\mathrm{Si}-0.5-0.6$; $\mathrm{Al}, \mathrm{Fe}, \mathrm{Na}, \mathrm{K}, \mathrm{Rb}, \mathrm{Ba}-$ 1.5-5; Ti, Mn, Mg, Ca, P, Zr, Sr, Y, La, Ce, Nd, Nb, Pb, Th, Cu, $\mathrm{Zn}, \mathrm{Ga}, \mathrm{Cd}, \mathrm{Cs}-5-15 ; \mathrm{S}, \mathrm{Cl}-15-30$ relative $\%$. In the case of point samples more significant analytical uncertainty was noticed only for $\mathrm{Zr}$ (up to $15-25$ relative $\%$ ).

All the samples underwent detailed research in thin sections. Heavy mineral concentrates were studied additionally for the bulk ones to investigate complete mineralogical composition. All mineral phases studied were reanalyzed using electron microprobe to validate previous qualitative mineral analysis. 
Whole-rock data set for main types of Perga area altered rocks is based on final results of analytical and mineralogical research (Table 1-3). This data set includes additional geochemical data obtained for the Korosten pluton granitoids earlier (Lazareva, 2015; Shnyukov, 2001; Shnyukov, 2002; Shnyukov and Lazareva, 2002; Shnyukov et al., 2000; Shnyukov et al., 2018 etc.).

Modal mineralogical composition of selected unaltered rocks and metasomatites of Perga area

Table 1

\begin{tabular}{|c|c|c|c|c|c|c|c|c|c|c|}
\hline Mineral & 1 & 2 & 3 & 4 & 5 & 6 & 7 & 8 & 9 & 10 \\
\hline K-feldspar, vol\% & 48 & 45 & 50 & 60 & 48 & 34 & 30 & 40 & 20 & 15 \\
\hline Plagioclase, vol\% & 16 & 9 & 3 & - & - & - & - & - & - & - \\
\hline Albite, vol\% & - & 5 & 2 & 10 & 15 & 14 & 11 & 20 & 5 & 60 \\
\hline Ferrimuscovite, vol\% & - & - & 2 & - & - & - & - & 5 & - & - \\
\hline Biotite, vol\% & 3 & 1 & 3 & 5 & 5 & 5 & 3 & $25^{*}$ & $30^{*}$ & 2 \\
\hline Genthelvite, ppm & - & - & - & - & - & 27 & 17268 & 4132 & 222828 & 1871 \\
\hline Blende, $\mathrm{ppm}$ & - & - & - & - & - & 93 & 77 & - & - & - \\
\hline Cassiterite, ppm & - & - & 1 & 16 & 428 & - & 18 & - & 1532 & 25904 \\
\hline Monazite, ppm & - & - & - & - & - & - & - & - & 7507 & - \\
\hline Xenotime, $\mathrm{ppm}$ & - & - & - & - & - & - & 3 & - & - & - \\
\hline Molybdenite, ppm & - & 1 & 2 & - & 298 & - & 22 & - & - & - \\
\hline Anatase, $\mathrm{ppm}$ & - & - & - & 3 & - & 3 & 8 & - & - & - \\
\hline Perovskite, ppm & - & - & - & - & - & - & - & 15 & - & - \\
\hline Thorite, ppm & - & - & - & 5 & - & - & - & - & - & - \\
\hline Phenakite, ppm & - & - & - & - & - & - & - & 124 & - & - \\
\hline Weberite, ppm & - & - & - & - & 17073 & - & - & - & - & - \\
\hline Magnetite, ppm & 483 & 8 & 309 & 7 & 28 & 13 & 12 & 124 & - & 25 \\
\hline Hematite, ppm & - & 3 & - & - & 326 & 1429 & - & 1374 & 159 & 446 \\
\hline Bastnasite, ppm & - & - & - & 1 & - & - & - & - & - & - \\
\hline Epidote, ppm & - & 4 & - & - & - & - & - & - & - & 4 \\
\hline
\end{tabular}

Notes: (1) 1-3 - Korosten granitoids (1 - unaltered, 2 and 3-weakly altered varieties); 4, 5-ordinary metasomatic granites of Perga type; 6 - granites of Perga type with redistributed quartz; 7, 8 and 9 - quartz-albite-microcline, siderophyllite-feldspar (siderophyllite-albitemicrocline) and siderophyllite metasomatites respectively; 10 - albitites-Il. (2) * siderophyllite.

\section{Main types of metasomatites description}

Among metasomatically altered rocks of the Perga area the most widespread and typical varieties were investigated (Bespalko, 1975; Galetsky and Zinchenko, 1971; Galetsky, 1974; Esipchuk et al., 1993; Metalidi and Nechaev, 1983 etc.), substratum for formation of which were granitoids. Two series of rock varieties subsequently replacing each other were distinguished among them. Their mineral and chemical compositions are given in Tables 1,2 and 3.

The first series includes:

(1) Ordinary metasomatic granites of Perga type. Brownish to grey-rosy in color, mainly medium-grained and uneven-grained, in some cases porphyry varieties. Characteristic gneissic banding is caused by parallel arrangement of lenticular biotite scales. Texture varies from blastogranitic to protoclastite with crystaloblastic cement, with minor porphyroblastic. The rocks of first series are most widely distributed in the Perga area. They are originated from Korosten pluton granitoids, which is proved by the presence of transition and altered in a various degree varieties (apogranites). The age of the Perga granites, estimated by U-Pb method (zircon) yields 1760-1730 Ma (Kovalenko, 1979; Sherbakov, 2005).

(2) Granites of Perga type with redistributed quartz. These are pink-reddish medium-grained, massive, with minor gneissic banding rocks with newly formed aggregations of bluish quartz grains. They possess similar structure and texture to Perga granites. Small lenses and irregular-shaped bodies among ordinary granites of Perga type are typical for the variety, gradually passing into quartzalbite-orthoclase and actually feldspar metasomatites.

(3) Quartz-albite-microcline metasomatites. Light pink, medium- to fine-grained, massive varieties with poorly distinguishable gneissic banding. They have heteroblastic to minor granoblastic texture. Aggregations of quartz are common and charecterized by granoblastic texture. Such metasomatites form separate vein-shaped bodies among granitoids or compose peripheral zones of the bodies that consist of rocks varieties described below.

(4) Feldspar metasomatites are represented by leucocratic, mainly medium-grained varieties. They show metasomatic textures similar to that of cryptocrystalline panidiomorphic texture of intrusive rocks. Albite-microcline (more widespread), microcline-albite varieties and albitites-l are distinguished among them. This classification is based on the primary microcline/secondary albite ratio. Feldspar metasomatites are the basic ore-bearing varieties that mostly occur at the central parts of the economic metasomatic bodies.

(5) Siderophyllite-feldspar metasomatites are massive, with minor gneissic banding varieties and blastocataclastic, protoclastite, and sometimes porphyroclastic texture. They form irregular-shaped bodies in common metasomatites. It is possible to distinguish siderophyllite-albite-microcline and siderophyllitemicrocline-albite varieties among them depending on variety of primary feldspar metasomatites.

(6) Siderophyllite metasomatites. Dark gray finegrained gneissic varieties with lepidogranoblastic and rare porphyroclastic texture. They compose thin zones among their bodies.

The second series is represented by a single variety, quartz-muscovite greisens. These are green- to light grey, unevenly colored coarse-schistose rocks. They are characterized by porphyryblastic texture with lepidogranoblastic matrix and compose small elongated 
bodies confined to zones of cataclastic rocks and mylonite formation processes. The second series was found in every unaltered variety of the Korosten granites and apogranites except for the Perga type. Gradual transitions from the host rocks to greisen bodies are evident and therefore their texture varies over a wide range.

Table 2

\begin{tabular}{|c|c|c|c|c|c|c|c|c|c|c|c|c|c|}
\hline \multicolumn{14}{|c|}{ ajor element average composition of unaltered rocks and metasomatites of Perga area (wt\%) } \\
\hline Oxide, element & 1 & 2 & 3 & 4 & 5 & 6 & 7 & 8 & 9 & 10 & 11 & 12 & 13 \\
\hline $\mathrm{SiO}_{2}$ & 75.628 & 75.857 & 75.383 & 76.780 & 66.293 & 70.036 & 66.892 & 61.866 & 65.501 & 47.583 & 69.395 & 75.380 & 85.842 \\
\hline $\mathrm{TiO}_{2}$ & 0.209 & 0.126 & 0.115 & 0.068 & 0.114 & 0.084 & 0.045 & 0.171 & 0.153 & 0.311 & 0.015 & 0.161 & 0.096 \\
\hline $\mathrm{Al}_{2} \mathrm{O}_{3}$ & 12.177 & 11.656 & 12.276 & 11.862 & 17.577 & 15.516 & 18.767 & 17.810 & 15.691 & 14.148 & 16.621 & 12.593 & 8.091 \\
\hline $\mathrm{Fe}_{2} \mathrm{O}_{3}^{\text {total } *}$ & 2.114 & 2.590 & 2.390 & 1.366 & 2.182 & 2.008 & 1.669 & 4.983 & 3.792 & 18.569 & 0.301 & 2.325 & 1.513 \\
\hline $\mathrm{MnO}$ & 27 & 31 & 25 & 28 & 040 & 115 & .053 & 106 & 0.265 & 0.580 & .025 & 0.033 & 0.025 \\
\hline $\mathrm{MgO}$ & 125 & 072 & 059 & 053 & .070 & .071 & .095 & 147 & .093 & .217 & 33 & .157 & 0.182 \\
\hline $\mathrm{CaO}$ & 0.524 & 0.592 & 0.481 & 0.282 & 0.400 & 0.227 & 0.153 & 0.400 & 0.733 & 0.788 & 0.098 & 0.506 & 0.001 \\
\hline $\mathrm{Na}_{2} \mathrm{O}$ & & 3.517 & 3.680 & 2.975 & 5.179 & 5.590 & 9.805 & 3.310 & 06 & 1.114 & 10.237 & 2.825 & 0.047 \\
\hline $\mathrm{K}_{2} \mathrm{O}$ & 34 & 4.527 & 4.726 & & 33 & 4.894 & 1.243 & 67 & 25 & 9.217 & 0.325 & 4.777 & 2.613 \\
\hline $\mathrm{P}_{2} \mathrm{O}_{5}$ & & & & & & 0.012 & & & 0.014 & 0.043 & 0.012 & 0.011 & 0.012 \\
\hline$S$ & 95 & 81 & 0.095 & 0.135 & 0.067 & 0.165 & 0.102 & 0.199 & 0.213 & 0.502 & 0.101 & 0.027 & 0.018 \\
\hline $\bar{C}$ & 09 & 509 & 0.009 & 0.009 & 0.023 & 0.008 & 0.024 & 0.025 & 0.009 & 0.094 & 0.005 & 0.008 & 0.004 \\
\hline $\mathrm{LOI}-(\mathrm{S}+\mathrm{C}$ & 455 & 0.544 & 0.378 & 0.231 & 0.389 & 0.342 & 0.456 & 1.017 & 0.585 & 0.981 & 0.271 & 0.953 & 1.402 \\
\hline $\mathrm{TE}^{\star *}$ & 0.214 & 0.386 & 0.372 & 0.448 & 0.613 & 0.941 & 0.678 & 1.574 & 2.609 & 6.085 & 2.642 & 0.244 & 0.154 \\
\hline Total & 99.998 & 99.999 & 99.998 & 100.02 & 99.998 & 100.01 & 99.996 & 99.993 & 99.989 & 100.23 & 100.08 & 99.999 & 100.01 \\
\hline Density, $\mathrm{g} / \mathrm{cm}^{3}$ & 2.610 & 2.624 & 2.631 & 2.604 & 2.632 & 2.621 & 2.612 & 2.706 & 2.688 & 3.031 & 2.600 & 2.609 & 2.702 \\
\hline
\end{tabular}

Notes: (1) Rock varieties of the $1^{\text {st }}$ alteration type: 1 - unaltered Korosten granitoids (substratum for alteration); 2 - ordinary metasomatic granites of Perga type; 3 - granites of Perga type with redistributed quartz; 4, 5 and 6 - quartz-albite-microcline, albite-microcline and microcline-albite metasomatites respectively; 7 - albitites-I; 8, 9 and 10 - siderophyllite-albite-microcline, siderophyllite-microcline-albite and siderophyllite metasomatites respectively; 11 - albitites-II (probably of 1a alteration type). Rock varieties of the $2^{\text {nd }}$ alteration type: 12 unaltered or weakly altered Korosten granitoids (substratum for alteration); $13=$ quartz-muscovite greisens. (2) $\mathrm{Fe}_{2} \mathrm{O}_{3}$ total $=$ all $\mathrm{Fe}$ as $\mathrm{Fe}_{2} \mathrm{O}_{3}$. (3) TE - total trace elements content as oxides.

Trace element average composition of unaltered rocks and metasomatites of Perga area (ppm)

\begin{tabular}{|c|c|c|c|c|c|c|c|c|c|c|c|c|c|}
\hline Element & 1 & 2 & 3 & 4 & 5 & 6 & 7 & 8 & 9 & 10 & 11 & 12 & 13 \\
\hline $\mathrm{Cu}$ & 30 & 45 & 39 & 52 & 53 & 88 & 76 & 137 & 219 & 403 & 44 & 28 & 25 \\
\hline $\mathrm{Zn}$ & 167 & 1030 & 1028 & 1763 & 1754 & 7561 & 4830 & 17429 & 21754 & 52023 & 1723 & 178 & 195 \\
\hline $\mathrm{Ga}$ & 21 & 33 & 30 & 38 & 45 & 57 & 95 & 123 & 122 & 303 & 54 & 28 & 19 \\
\hline $\mathrm{Rb}$ & 337 & 919 & 857 & 1033 & 1285 & 935 & 450 & 1880 & 1140 & 4068 & 31 & 491 & 357 \\
\hline $\mathrm{Sr}$ & 44 & 31 & 26 & 19 & 26 & 16 & 9 & 29 & 24 & 70 & 5 & 32 & 19 \\
\hline $\mathrm{Y}$ & 71 & 152 & 155 & 159 & 265 & 146 & 110 & 247 & 285 & 373 & 22 & 115 & 57 \\
\hline $\mathrm{Zr}$ & 349 & 533 & 500 & 475 & 640 & 589 & 473 & 707 & 658 & 794 & 31 & 469 & 262 \\
\hline $\mathrm{Nb}$ & 43 & 174 & 142 & 116 & 248 & 121 & 43 & 252 & 265 & 284 & 496 & 96 & 61 \\
\hline $\mathrm{Pb}$ & 34 & 42 & 45 & 34 & 100 & 196 & 177 & 154 & 817 & 138 & 12 & 54 & 39 \\
\hline Th & 24 & 51 & 36 & 44 & 59 & 64 & 33 & 89 & 100 & 104 & $\leq 5$ & 38 & 25 \\
\hline $\mathrm{Ba}$ & 284 & 24 & 31 & 37 & 49 & 47 & 28 & 58 & 36 & 122 & 8 & 106 & 68 \\
\hline La & 119 & 86 & 102 & 62 & 245 & 64 & 23 & 125 & 97 & 166 & 6 & 131 & 61 \\
\hline $\mathrm{Ce}$ & 195 & 148 & 168 & 110 & 413 & 107 & 43 & 221 & 174 & 278 & 12 & 214 & 105 \\
\hline $\mathrm{Nd}$ & 79 & 49 & 58 & 31 & 131 & 34 & $<20$ & 69 & 56 & 99 & $<10$ & 70 & 24 \\
\hline $\mathrm{Sn}$ & 20 & 75 & 49 & 65 & 76 & 86 & 51 & 109 & 141 & 170 & 18644 & $<20$ & $<20$ \\
\hline $\mathrm{Cd}$ & $<20$ & $<20$ & $<20$ & $<20$ & 12 & 31 & 13 & 20 & 83 & 57 & 36 & $<20$ & $<20$ \\
\hline $\mathrm{Cs}$ & $<20$ & $<20$ & $<20$ & $<20$ & $<20$ & $<20$ & $<20$ & $<20$ & $<20$ & 105 & $<20$ & $<20$ & $<20$ \\
\hline
\end{tabular}

Note: Column (rock types) numbers are the same as in Table 2.

Albitites-Il occupy specific position among the investigated types of rocks. Their structural relation with other types of metasomatites is insufficiently studied until now. Albitites-Il are light gray or white massive fine-grained rocks which texture reminds the alotriomorphic one. Albitites-II occur as veinlets that crosscut bodies of the first series feldspar metasomatites, but distinctly differ from them in mineralogical composition. Cassiterite is the main accessory mineral which content reaches ore levels. In the present paper albitites-II are conditionally referred to $1 \mathrm{a}$ alteration series.

5. Major and trace element behavior during the metasomatites formation

Weight content (representative average data shown in Tables 2 and 3), transformed into the estimations of atomic amounts in reference rock volume $\left(10000 \mathrm{~cm}^{3}\right)$ (Kazitsyn and Rudnik, 1968): $\mathrm{N}_{i}=\mathrm{A}_{i} \cdot \mathrm{d} / 16.6$, where $\mathrm{d}$ - rock density $\left(\mathrm{g} / \mathrm{cm}^{3}\right), \mathrm{A}_{i}=1000 \mathrm{n}_{i} \cdot \mathrm{C}_{i} / \mathrm{M}_{i}\left(\mathrm{C}_{i}-\right.$ element $i$ oxide content in rock, wt \%; $M_{i}$ - element $i$ oxide molecular weight; $\mathrm{n}_{i}-$ amount of element $i$ atoms in oxide) or $\mathrm{A}_{i}=1000 \mathrm{C}_{i} / \mathrm{M}_{i}\left(\mathrm{C}_{i}-\right.$ element $i$ content in rock, wt \%; $\mathrm{M}_{i}-$ its atomic weight) was used to study mass balance and element behavior for major and trace elements respectively to take into account rock density variations during metasomatic processes.

Significant major element migration is noticed only for $\mathrm{Si}$, $\mathrm{Na}, \mathrm{K}, \mathrm{Al}, \mathrm{Fe}, \mathrm{Mg}$ and $\mathrm{Ca}$. It is accompanied by significant efflux and influx of many important trace chalco- and lithophylic elements. As a result, concentration of many of them reaches practically economic levels (Table 3 ). Si as major element with especially contrast and regular behavior most unequivocally characterizes possible trend and degree of alteration process. Therefore, this element lies in a basis of chemical types of rocks metasomatic alterations systematization. The estimations obtained are summarized on diagrams of selected major and trace elements behavior plotted as function of $\mathrm{N}_{\mathrm{Si}}$ (Fig. 3-7). These diagrams show the main features of mass balance during the formation of ore-bearing metasomatites of Perga area. 

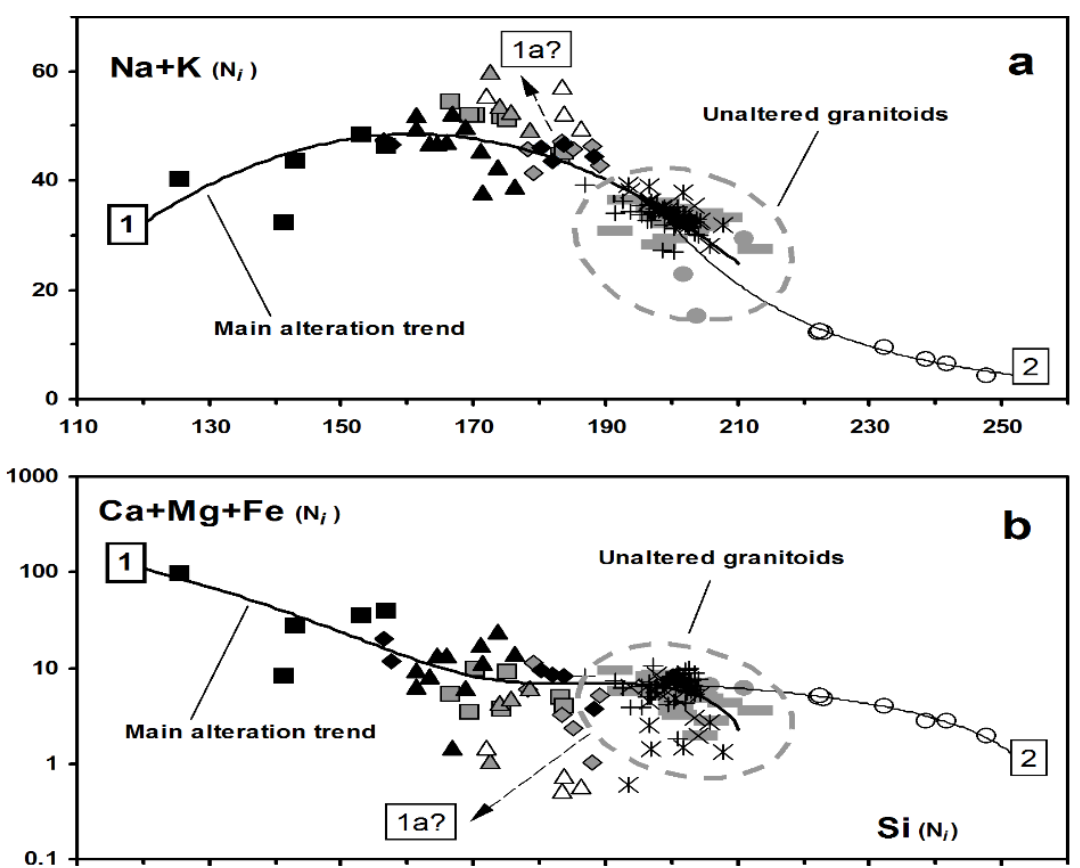

Fig. 3. General chemical typification of rocks alteration in ore-bearing metasomatic zones of Perga area spatially associated with Korosten pluton granitoids. Defined alteration types (numbered trends) are presented on $\mathrm{Na}+\mathrm{K}(\mathrm{a})$ and $\mathrm{Ca}+\mathrm{Mg}+\mathrm{Fe}$ (b) vs. Si graphs (in $\mathrm{N}_{i}$ units).

Varietes of the $1^{\text {st }}$ alteration type: gray rectangles - unaltered Korosten granitoids (substratum for alteration); black crosses, oblique crosses and stars - ordinary metasomatic granites of Perga type, their varietes with redistributed quartz and metasomatites of quartz-albite-microcline composition respectively; gray squares, rhombuses and triangles - albite-microcline, microcline-albite metasomatites and albitites-l; black filled triangles and rhombuses - siderophyllite-feldspar metasomatites formed as a result of albite-microcline and microcline-albite metasomatites alteration respectively; filled black squares - siderophyllite metasomatites; unfilled triangles - albitites-II (probably of 1a alteration type).

Varietes of the $2^{\text {nd }}$ alteration type: gray circles - unaltered or weakly altered Korosten granitoids (substratum for alteration); unfilled circles - quartz-muscovite greisens. See text for metasomatic rock types description and additional explanations

Based on the data obtained (Fig. 3-7) all studied alteration varieties were classified into several geochemical types of alteration that resulted in formation of corresponding metasomatites during the multistage metasomatic processes:

(1) Fe-Mg-Na-K-Zn, Pb, Nb, Rb, Cs, Cd (Be, Li, Ta etc.) - Perga granites (both types), quartz-albitemicrocline, feldspar, siderophyllite-feldspar and siderophyllite metasomatites;

(1a?) $\mathrm{Na}-\mathrm{Nb}, \mathrm{Sn}$ (Ta, Be etc.) - albitites-II;

(2) $\mathrm{Si}-(\mathrm{Sn}, \mathrm{Be}, \mathrm{W}$ etc.) - quartz-muscovite greisens.
Elements that were not studied in this work are placed in brackets for all classified types, but they are known to be intensively accumulated during metasomatism (Galetsky, 1974; Esipchuk et al., 1993; Shatskaya and Shpanov, 1977 etc.). First geochemical type of alteration plays a key role within the Perga area due to outcrops abundance of corresponding metasomatites and high economic mineralization. Therefore, average composition of these metasomatites (Tables 2 and 3) were used to compare to the results of geochemical modelling.
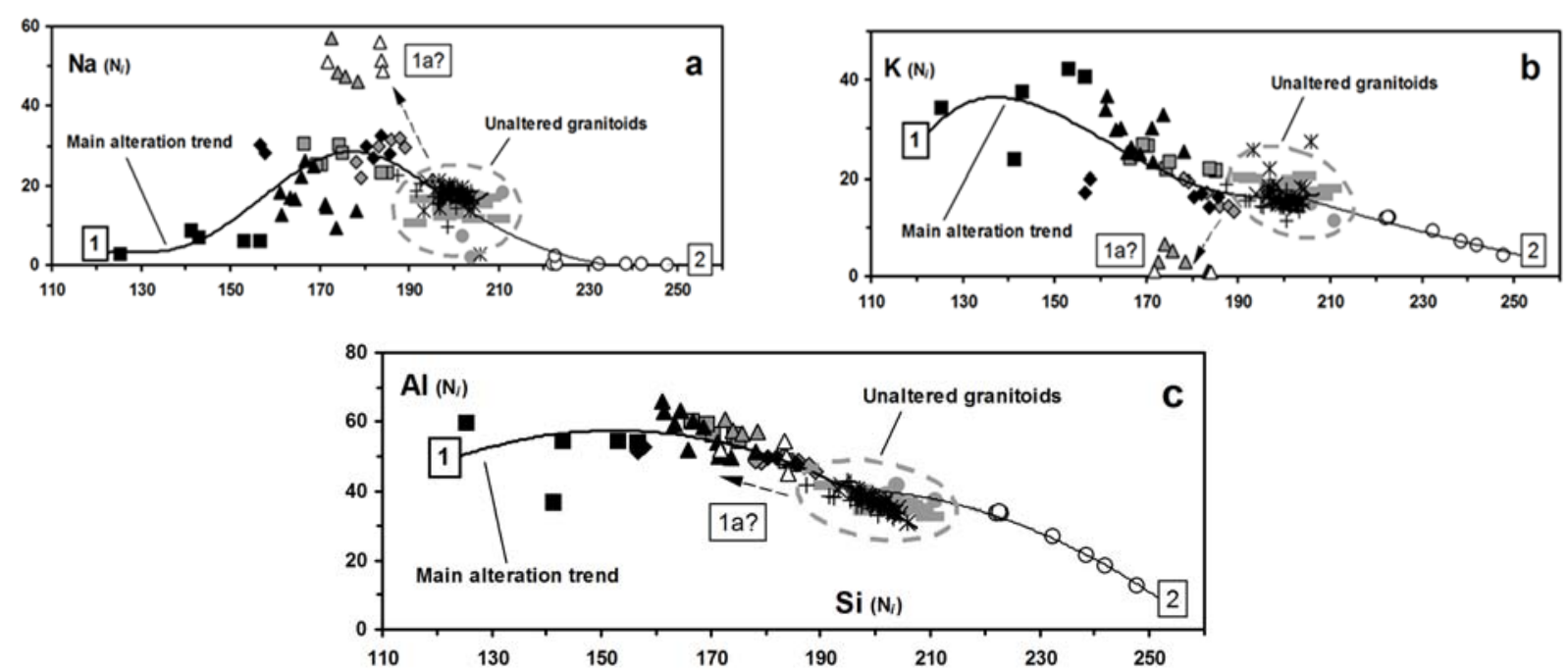

Fig. 4. $\mathrm{Na} \mathrm{(a),} \mathrm{K}(\mathrm{b})$ and $\mathrm{Al}$ (c) behavior during the rocks alteration in ore-bearing metasomatic zones of Perga area spatially associated with Korosten pluton granitoids. Element concentrations are in $\mathbf{N}_{i}$ units. Rock types symbols and trends numbers are the same as on Fig. 2. See text for additional explanations 

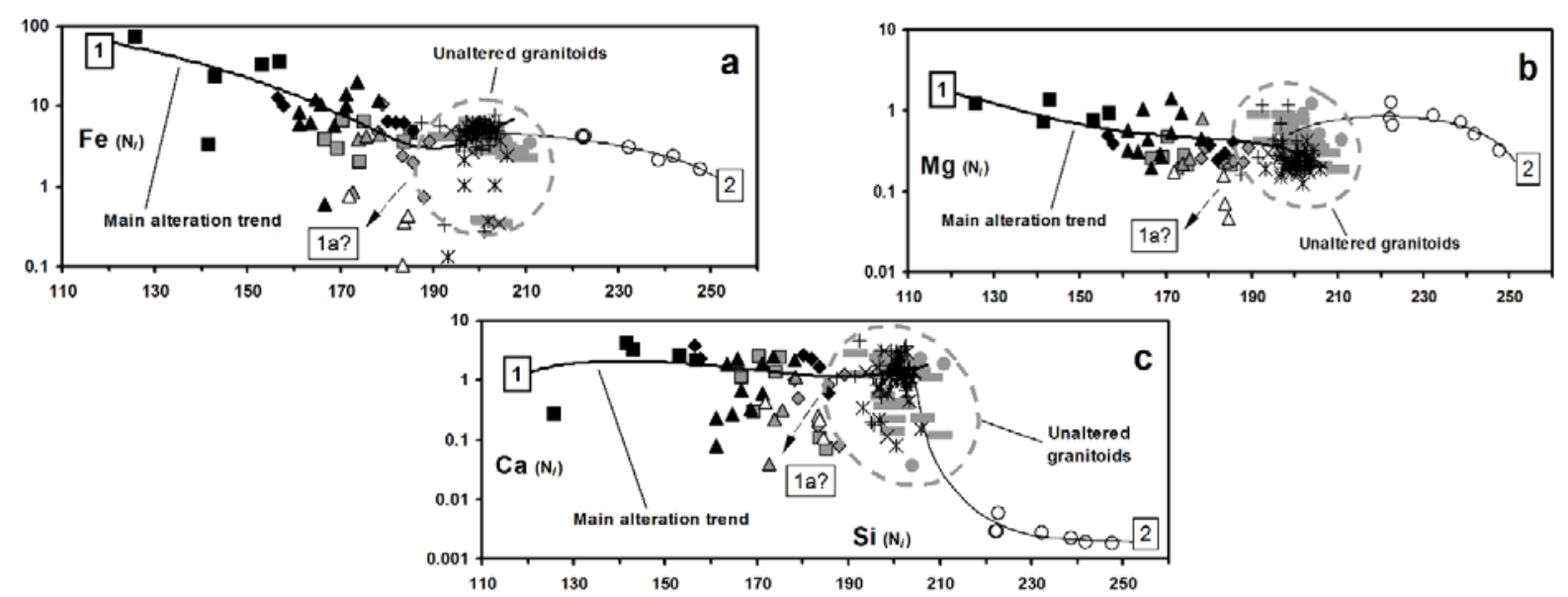

Fig. 5. Fe (a), $\mathrm{Mg} \mathrm{(b)}$ and $\mathrm{Ca}$ (c) behavior during the rocks alteration in ore-bearing metasomatic zones of Perga area spatially associated with Korosten pluton granitoids. Element concentrations are in $\mathbf{N}_{i}$ units. Rock types symbols and trend numbers are similar to Fig. 2. See text for additional explanations

\section{Modelling procedure \\ 6.1. Initial data for geochemical modelling of altered rocks formation}

Geochemical modelling of altered rocks formation was based on geochemical model of Korosten pluton granitoids magmatic evolution prepared earlier (Lazareva, 2015; Shnyukov, 2001; Shnyukov, 2002; Gavryliv et al., 2016; Lazareva et al., 2017; Shnyukov et al., 2000; Shnyukov et al., 2018 etc.) using representative geochemical data set that covers their main varieties (rapakivi, granite-porphyry, veined granites etc.) and Rayleigh fractional crystallization model to approximate the trace element data. Following crucial results were derived from this "magmatic" model for use in altered rocks formation geochemical modelling:

(1) Typical incompatible behavior with approximately constant bulk distribution coefficient was determined for $\mathrm{Rb}$ $\left(D_{\mathrm{Rb}}=0.5\right)$. Model $f$ values (weight fraction of liquid phase in magma chamber) were calculated for each granitoid type (residual melt portion) from Rayleigh equation and $\mathrm{Rb}$ content in rocks $\left(\mathrm{C}_{\mathrm{Rb}}\right)$ assuming minimum concentration in granitoids (169 ppm) as Rb content in parent magma $\left(\mathrm{C}_{0} \mathrm{Rb}\right)$.

(2) C vs. $f$ curves for trace (including $\mathrm{P}, \mathrm{Ti}, \mathrm{S}, \mathrm{Cl}, \mathrm{F}$, and $\mathrm{Ca}$ ) and major elements were approximated by means of $\mathrm{C}=\mathrm{C}_{0} \cdot f^{\mathrm{D}-1}$ equations or polynomial ones respectively (Fig. 8, b and 8, c). Parameters of these equations, corresponding bulk distribution coefficient $(D)$ and $\mathrm{C}_{0}$ values for trace elements are represented in Table 4. Obtained $D$ values are realistic (Fig. 9, b). This set of equations is an idealized model of elements behavior that demonstrates depletion in $\mathrm{Ba}, \mathrm{Sr}, \mathrm{Ti}, \mathrm{Zr}, \mathrm{P}, \mathrm{S}$ and enrichment in $\mathrm{Th}$ and $\mathrm{Ga}$ in the residual liquid as well as the inversion type of LREE, $\mathrm{Y}, \mathrm{F}, \mathrm{Cl}, \mathrm{Nb}, \mathrm{Zn}$ and $\mathrm{Pb}$ behavior during the melt fractional crystallization in magma chamber. Monotonous decrease of both $\mathrm{Zr}$ and $\mathrm{P}$ content indicates melt saturation in zircon and apatite. Therefore, the model temperature ( $\left.T_{\text {model }}\right)$ of the melt was estimated using experimental equations for zircon and apatite solubility (Harrison and Watson, 1984; Watson and Harrison, 1983). The temperature evolution in magma chamber is presented as Tmodel vs. $f$ polynomial equation (Tmodel range: $900-720^{\circ} \mathrm{C}$ ) (Fig. 10, d).

(3) Inversion in LREE content ( $f=0.185)$ indicates the apatite/monazite replacement in the crystallizing material. Water content in melt for this $f$ value for corresponding Tmodel was calculated from monazite solubility equation (Montel, 1993) which demonstrates its high $\mathrm{H}_{2} \mathrm{O}$ dependence, which yielded $\mathrm{C}_{0}{ }^{\mathrm{H} 2 \mathrm{O}}=2.36 \mathrm{wt} \%$ (assuming $\left.D_{\mathrm{H} 2 \mathrm{O}}=0.1\right)$ for the liquidus of initial granite melt ( $P_{\text {total }} \sim 6.3$ kbar corresponds to this value (Ryabchikov, 1975; Harrison and Watson, 1984)) (Fig. 8, a).
(4) According to the model designed, water saturation limit was reached at $f=0.165$ and $\mathrm{H}_{2} \mathrm{O}$-fluid was extracted from the melt during its further evolution (Fig. 8, a). Synchronous inversion of $\mathrm{C}$ vs. $f$ behavior (Fig. 8, b) proves fluid enrichment with $\mathrm{F}, \mathrm{Cl}, \mathrm{Nb}, \mathrm{Zn}, \mathrm{Pb}$ etc.

Elements with inversion type behavior for the entire data set (Fig. 8, b and 8,c) indicate the beginning of aqueous fluid separation from the melt at the lower $f$-parameter value $(f=0.123)$.

6.2. Calculation of the trace element fluid/melt distribution coefficients

The set of parameters calculated from the "magmatic" model, especially crystal/melt bulk distribution coefficient (D) and $f$ parameter at the beginning of aqueous fluid separation from the melt $\left(f_{i n v}\right)$, allows us to calculate fluid/melt distribution coefficient values for elements with inversion behavior $(\mathrm{F}, \mathrm{Cl}, \mathrm{Nb}, \mathrm{Zn}, \mathrm{Pb})$. The theoretical background and procedure of the calculation are given below.

If fractional crystallization is the main factor of magmatic system evolution, trace elements behavior can be described using the well-known Rayleigh equation assuming that their bulk distribution coefficients are constant (Ryabchikov, 1975; Neumann et al., 1954 etc.):

$$
C=C_{0} \cdot f^{D-1}
$$

where $\mathrm{C}$ is the trace element concentration in the residual melt, $\mathrm{C}_{0}$ is the initial trace element content in the parent melt, $D$ is the bulk distribution coefficient for this element, and $f$ is the weight fraction of liquid (melt) in the system. According to predesigned "magmatic" model (Lazareva, 2015; Shnyukov, 2001; Shnyukov, 2002; Shnyukov and Lazareva, 2002; Shnyukov et al., 2000; Shnyukov et al., 2018 etc.), Korosten pluton represents this exact case.

Before the fluid phase emerges in the system parameter $f$ in equation (1) can be defined as:

$$
f=\frac{M^{L}}{\left(M^{L}+M^{S}\right)},
$$

where $M^{L}$ and $M^{S}$ are the masses of liquid and solid phases of the system respectively. Bulk distribution coefficient $(D)$ values for each element under the same condition are:

$$
D=a k_{i}^{x}+b k_{i}^{y}+\ldots+c k_{i}^{z},
$$

where $a, b, \ldots c$ are the weight fractions of each mineral $(x, y, \ldots z$ respectively $)$ in a solid phase composition; $k_{i}^{x}, k_{i}^{y}, \ldots k_{i}^{z}$ are the mineral/melt distribution coefficients of the element $i$ for these minerals $\left(k_{i}^{x}=C_{i}^{x} / C_{i}^{L}\right.$, where $C_{i}^{x}$ 
and $C_{i}^{L}$ are the concentrations of the element $i$ in mineral and melt respectively). According to designed "magmatic" model (Fig. 8, b and Table 4), the behavior of each of the inversion element can be described by two equations of type (1), which correspond to the stages of magmatic evolution before the beginning of fluid separation $\left(f<f_{\text {inv. }}\right.$ ) and after the inversion point $\left(f<f_{i n v}\right)$, which coincides with the

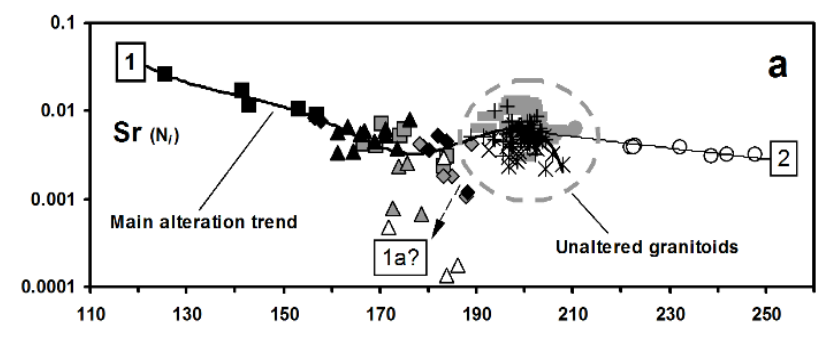

beginning of the fluid separation. Concentration values of each element in residual melt were calculated from the first and the second equations and denoted as $C^{M}$ and $C^{L}$, and corresponding bulk distribution coefficients as $D$ and $D^{\prime}$ respectively. $D$ and $D^{\prime}$ are approximately constant (Fig. 8, b) and their values are summarized in Table 4.

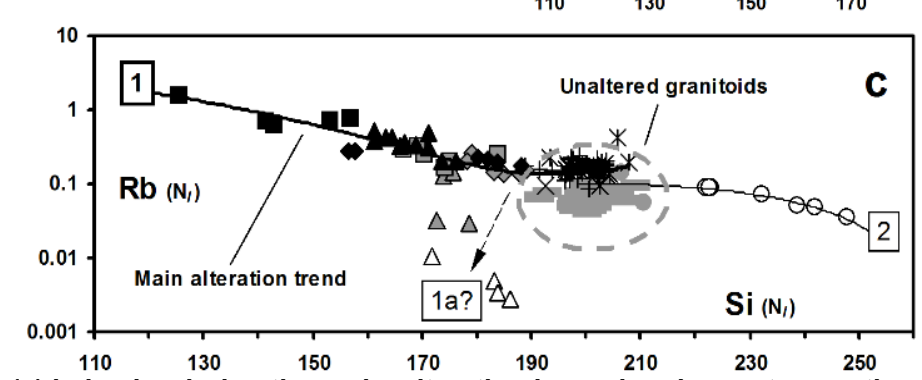

Fig. 6. $\mathrm{Sr}(\mathrm{a}), \mathrm{Ba}(\mathrm{b})$ and $\mathrm{Rb}$ (c) behavior during the rocks alteration in ore-bearing metasomatic zones of Perga area spatially associated with Korosten pluton granitoids. Element concentrations are in $\mathbf{N}_{i}$ units. Rock types symbols and trend numbers are similar to Fig. 2. See text for additional explanations
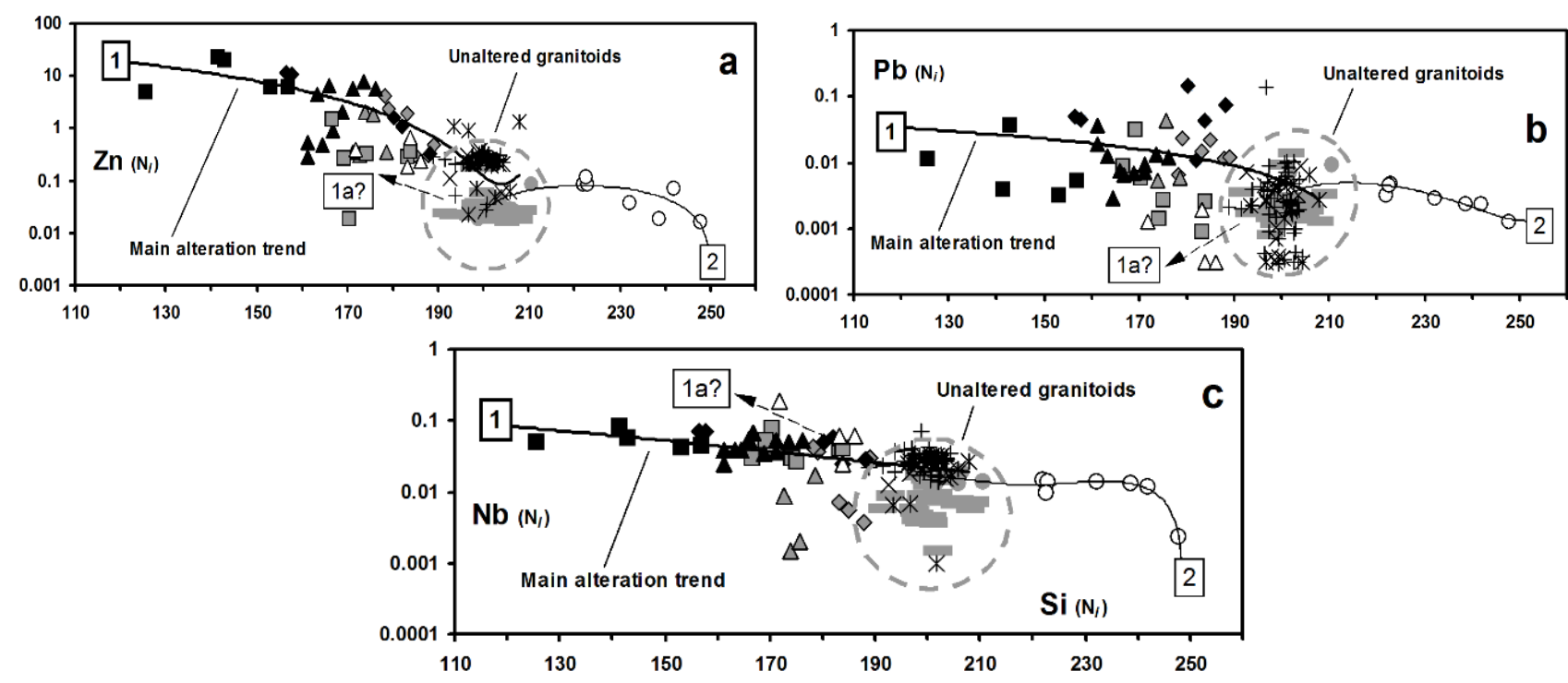

Fig. 7. $\mathrm{Zn} \mathrm{(a),} \mathrm{Pb}(\mathrm{b})$ and $\mathrm{Nb}$ (c) behavior during the rocks alteration in ore-bearing metasomatic zones of Perga area spatially associated with Korosten pluton granitoids. Element concentrations are in $\mathbf{N}_{i}$ units. Rock types symbols and trend numbers are similar to Fig. 2. See text for additional explanations 

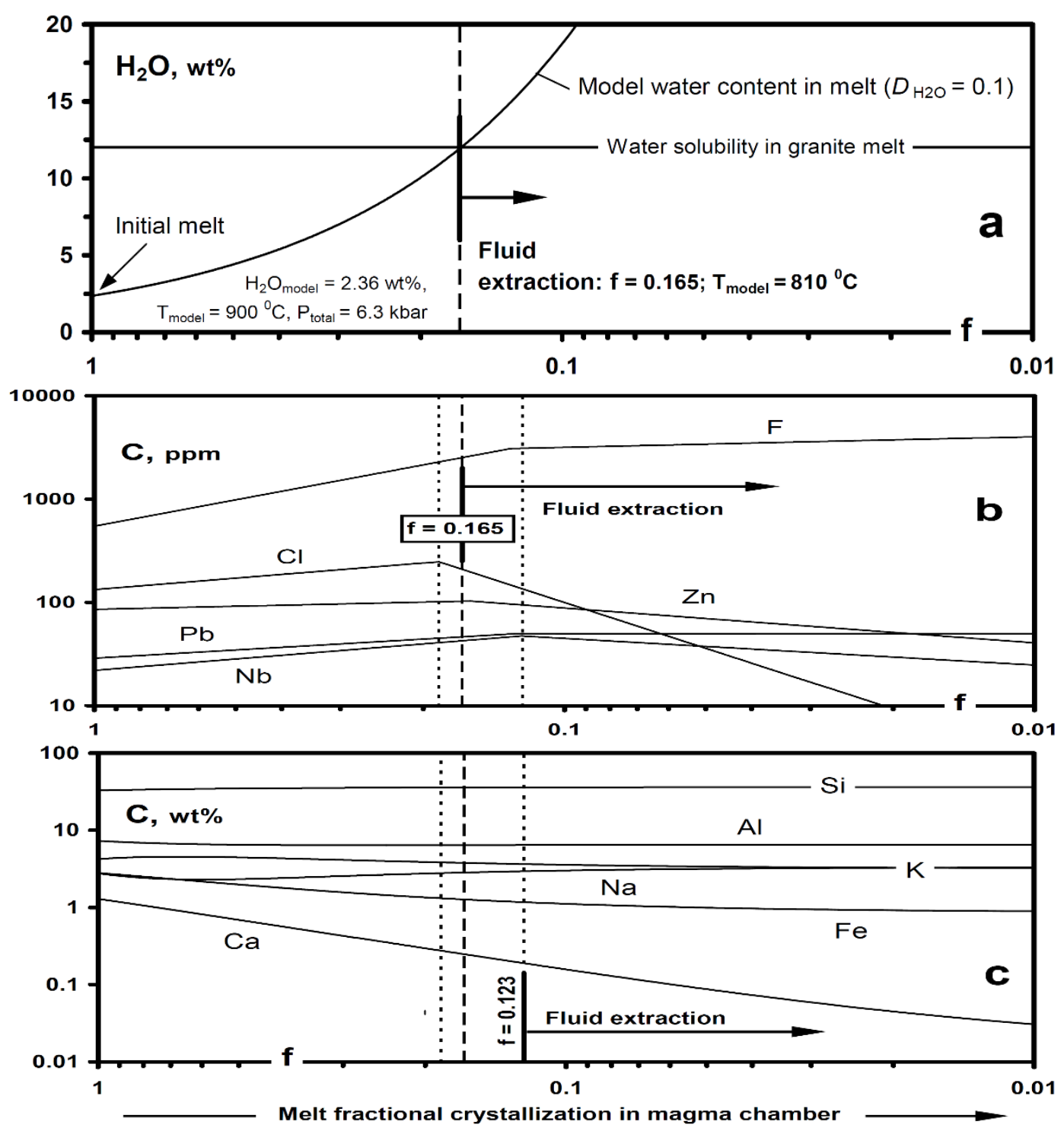

Fig. 8. Conditions of the aqueous fluid extraction from the melt (a), selected trace (b) and major (c) elements behavior during the Korosten pluton granitoids formation estimated assuming the magma fractional crystallization model. See text for additional explanations

After emergence of the fluid component in system $(f<$ $f_{i n v}$. $)$ the equation (1) remains valid, but on the condition that the equation (2) transforms into:

$$
f=\frac{M^{L}}{\left(M^{L}+M^{S}+M^{F}\right)},
$$

where $M^{F}$ is the mass of the fluid phase of the system. Certainly, $D^{\prime}$ is taking place of $D$, which values, similar to expression (3), are defined as:

$$
D^{\prime}=x D+y K^{F / L},
$$

where $x$ and $y$ are the mass fractions of the solid and fluid phases in the system respectively, excluding the liquid phase $(x+y=1)$, a $K^{F / L}$ - fluid/melt distribution coefficient for element with inversion type of behavior $\left(K^{F / L}=C^{F} / C^{L}\right.$, $C^{F}$ и $C^{L}$ - concentration of the element in the fluid and the melt respectively). Since $x=1-y$, the final equation (4) becomes: $D^{\prime}=D-y D+y K^{F / L}$. Hence:

$$
K^{F / L}=\frac{D^{\prime}-D+y D}{y} .
$$

Consequently, there is a necessity in $y$ parameter estimation to calculate $K^{F / L}$. The given model of magmatic evolution provides such possibility (Fig. 1, a, the works cited), which allows to estimate model water concentration value in the residual melt for any $f$ value and to define the separation of the aqueous fluid beginning moment upon reaching the solubility of water in it (Fig. 1, a). This gives the opportunity to estimate the "excessive" water concentration for the range of $f<f_{i n v}\left(\Delta C_{\mathrm{H}_{2} \mathrm{O}}^{f_{n}}\right.$,wt\%) - aqueous fluid formation resource, which separates during any period $\Delta f_{n}$ $\left(\Delta f_{n}=f_{n-1}-f_{n} ; n=1,2,3 \ldots n-\right.$ a number of conventional periods in the evolution of the system with the length of $\Delta f$ from the beginning of the separation of the aqueous fluid): $\Delta C_{\mathrm{H}_{2} \mathrm{O}}^{f_{n}}=C_{\mathrm{H}_{2} \mathrm{O}}^{f_{n}}-C_{\mathrm{H}_{2} \mathrm{O}}^{L}$, where $C_{\mathrm{H}_{2} \mathrm{O}}^{f_{n}}$ and $C_{\mathrm{H}_{2} \mathrm{O}}^{L}$ - respectively, model water concentration in the residual melt at the certain moment $f_{n}$ and $\mathrm{H}_{2} \mathrm{O}$ solubility in granitic melt (wt\%) under current conditions, which is buffering its actual concentration for the range $f<f_{\text {inv }}$. Hence: $\Delta F_{n}=0.01 \cdot \Delta C_{H_{2} O}^{f_{n}} \cdot \Delta f_{n}$, where $\Delta F_{n}$ - the proportion of the fluid phase in the system, 
separated during period $\Delta f_{n}$. The proportion of the solid phase in the system $(S)$ for any moment $f_{n}$ can be calculated using the expression: $S_{n}=1-\left(f_{n}+F_{n}\right)$, where $S_{n}, f_{n}, F_{n}$ ( $\left.F_{n}=\sum_{n=1}^{n} \Delta F_{n}\right)$ - the fractions of solid, liquid and fluid phases in the system respectively. The quantity of solid phase formed during the period $\Delta f_{n}$ can be easily estimated as: $\Delta S_{n}=S_{n-1}-S_{n}$. It is consequently easy to define $y$ (mass fraction of fluid phase in the system excluding the liquid phase) for each period of the evolution of the system $\Delta f_{n}$ :

$$
y=\frac{\Delta F_{n}}{\Delta F_{n}+\Delta S_{n}}
$$

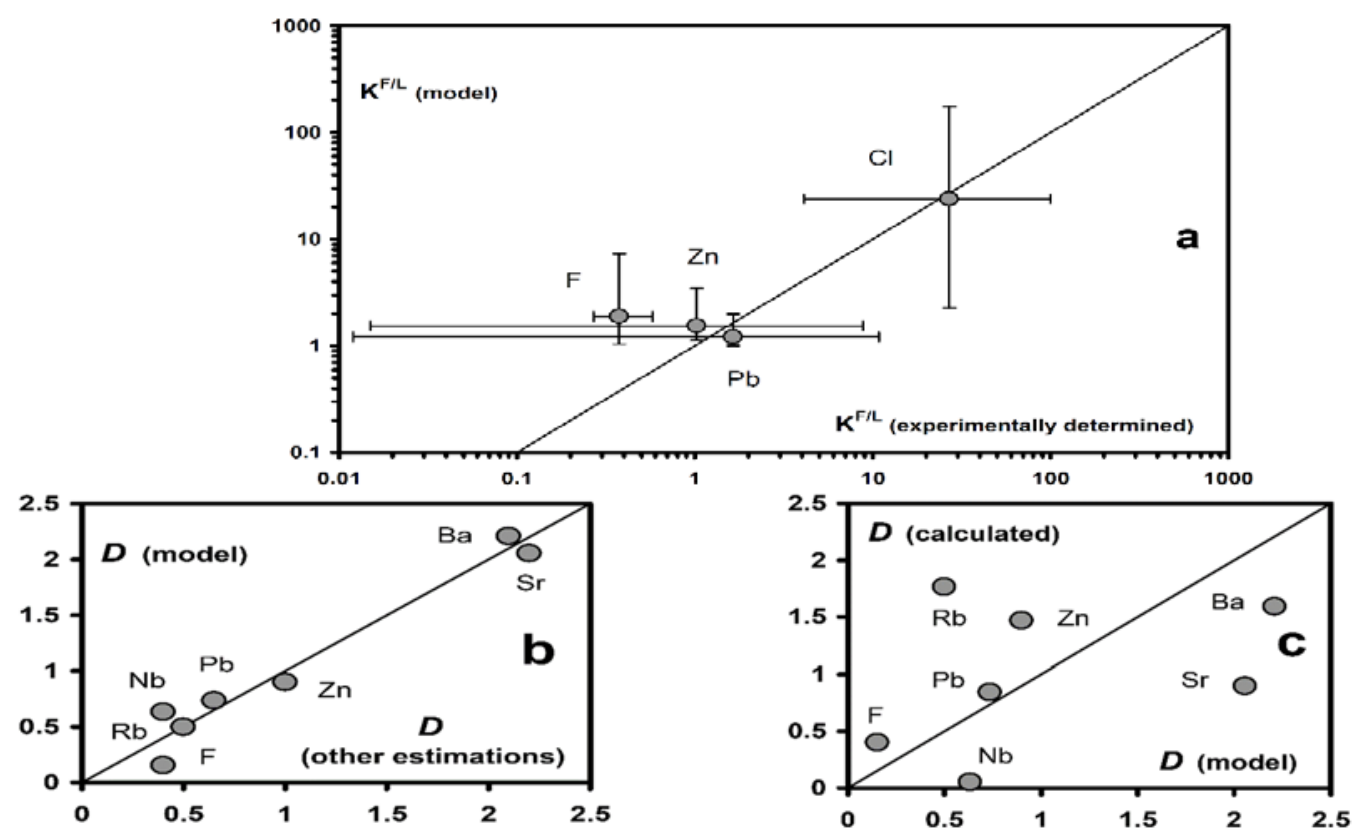

Fig. 9. Comparison of $K^{F / L}(a)$ and $D(b)$ values extracted from the geochemical model of Korosten granitoids formation (this work) with experimental (Kovalenko, 1979; Chevichelov and Epelbaum, 1985 etc.) and other estimations (Antipin et al., 1984; Ryabchikov, 1975 etc.) obtained for these parameters under the same conditions. Differences between the $D$ values calculated on a basis of rock-forming minerals distribution coefficient on high-temperature altered rocks composition modelling empirical data (Antipin et al., 1984; Ryabchikov, 1975 etc.) and $D$ values obtained from the model of granitoids formation are shown on Fig. $6 \mathrm{c}$. See text for additional explanations

$C_{0}$ and $D$ values calculated for selected elements on a base of $C$ vs. $f$ trends assuming that studied main Korosten granitoids rock types composition is as liquids (Lazareva, 2015; Shnyukov, 2001; Shnyukov, 2002; Shnyukov and Lazareva, 2002; Shnyukov et al., 2000; Shnyukov et al., 2018 etc.)

\begin{tabular}{|c|c|c|c|c|}
\hline \multirow{3}{*}{ Element } & \multicolumn{4}{|c|}{ Values calculated for various sections of C vs. $f$ trends } \\
\hline & \multicolumn{2}{|c|}{ Before inversion $(f>0.1 ? 0.2$} & \multicolumn{2}{|c|}{ After inversion $(f<0.1 ? 0.2)$} \\
\hline & $\mathrm{C}_{0}=a(\mathrm{ppm})$ & $D=b+1$ & $\mathbf{a}$ & $D=b+1$ \\
\hline $\mathrm{Zr}$ & 555.08 & 1.381 & ** & ** \\
\hline $\mathrm{Sr}$ & 119.99 & 2.0564 & ** & ** \\
\hline $\mathrm{P}$ & 497.04 & 2.172 & 9.4801 & 0.3058 \\
\hline $\mathrm{Ti}$ & 2622.7 & 1.7251 & ** & ** \\
\hline $\bar{Y}$ & 36.104 & 0.34 & 412.89 & 1.5363 \\
\hline LREE & 251.6 & 0.7182 & 2381.3 & 2.0511 \\
\hline $\mathrm{Rb}$ & $169^{*}$ & $0.5^{*}$ & ** & ** \\
\hline $\mathrm{Ba}$ & 1289.8 & 2.2094 & ** & ** \\
\hline $\mathrm{Zn}$ & 85.55 & 0.9 & 191.26 & 1.3368 \\
\hline $\mathrm{Ga}$ & 19.314 & 0.9346 & ** & ** \\
\hline Th & 11.428 & 0.5872 & $\star \star *$ & ** \\
\hline $\mathrm{Nb}$ & 21.991 & 0.6341 & 81.164 & 1.258 \\
\hline $\mathrm{Pb}$ & 28.841 & 0.7359 & 49.842 & 1.0001 \\
\hline $\mathrm{Cu}$ & 24.789 & 1.1069 & ** & ** \\
\hline$F$ & 547.41 & 0.153 & 2492.5 & 0.8963 \\
\hline $\mathrm{Cl}$ & 132.82 & 0.6315 & 2963.4 & 2.4732 \\
\hline$S$ & 780.15 & 1.418 & $* *$ & ** \\
\hline
\end{tabular}

Notes: (1) $a$ and $b$ are the parameters of the equations of $y=a x^{b}\left[C(p p m)=a f^{b}\right]$ form obtained for each trace element (Shnyukov, 2001; Shnyukov, 2002; Shnyukov et al., 2000; Shnyukov et al., 2018), (2) ${ }^{*}$ assumed values, (3) ${ }^{*} C$ vs. $f$ trends demonstrate the monotonous behavior of these elements without inversion points, (4) $L R E E=L a+C e+N d$, (5) inversion point $f$ values (finv.) for the elements extracted from the melt by $\mathrm{H}_{2} \mathrm{O}$-fluid are: $0.130(\mathrm{~F}), 0.185(\mathrm{Cl}), 0.159(\mathrm{Zn}), 0.126(\mathrm{~Pb}), 0.123(\mathrm{Nb})$.

Polynomial equations obtained for $C(w t \%)$ vs. $f$ trends of selected major elements are follows:

$y=-0.7893 x^{2}-2.7304 x+36.399$ (Si), $y=1.6734 x^{2}-0.8974 x+6.5034$ (Al), $y=2.8997 x^{2}-3.4556 x+3.3231$ (Na), $y=-2.9621 x^{2}+3.988 x+3.1936 \quad$ (K), $y=-0.1409 x^{2}+1.4169 x+0.0164$ (Ca), $y=-0.5874 x^{2}-0.8974 x+6.5034 \quad$ (Fe). 
Substituting (6) into equation (5) and performing simple transformations, we obtain the final equation for calculation of inversion behavior elements fluid/melt distribution coefficient for any value of $f_{n}$ :

$$
K^{F / L}=\frac{\Delta S_{n}\left(D^{\prime}-D\right)+D^{\prime} \Delta F_{n}}{\Delta F_{n}}
$$

For the elements with monotonous behavior, such as $\mathrm{Ba}$, $\mathrm{Sr}, \mathrm{Zr}$ and Th (Fig. 1), the expression (7) simplifies to the form $K^{F / L}=D$, their $D^{\prime}=D$ a-priori.

6.3. Evaluation of the separated $\mathrm{H}_{2} \mathrm{O}$-fluid composition

If the element content in residual melt $\left(C^{L}\right)$ is known, the $K^{F / L}$ values derived from the expression (7) allow calculating the inversion type element concentrations $\left(C^{F}\right)$ in the fluid, which was separated from the melt at any $f$ parameter values within the $\left(f<f_{\text {inv. }}\right)$ range:

$$
C^{F}=K^{F / L} \cdot C^{L} \text {. }
$$

Designed "magmatic" model provides all the data required (Table 4 , Fig. $8 b$ ).

$C^{F}$ values calculated for the elements with inversion type of behavior $(\mathrm{Zn}, \mathrm{Pb}, \mathrm{Nb})$ are very important parameters which may be used separately. For example, these values, coupled with fluid/liquid or fluid/whole system weight proportions derived from the expression (6), are useful for evaluation of ore elements total amounts, which were extracted from the melt during fluid separation. Therefore, $C^{F}$ combination with aforementioned complementary parameters is able to produce reliable estimations of ore-bearing potential of various magmatic complexes.

At the same time, $C^{F}$ values obtained for ore elements with inversion type behavior are to be supplied with data on $C^{F}$ values of other elements to generalize them in a complete set to use in altered rocks formation modelling. At least major elements with a leading role in mass balance during the natural metasomatic process must be included in this set. In the case of Perga area metasomatites such elements as $\mathrm{Si}, \mathrm{Na}, \mathrm{K}$ and $\mathrm{Fe}$ meet the mentioned requirements (see §5). Unfortunately, their $C$ vs. $f$ graphs show a simple type of behavior without any inversion points (Fig. 8, c) which makes it impossible to calculate the corresponding $K^{F / L}$ values in the aforementioned way. Therefore only the experimental results obtained for these most important major elements under conditions similar to those which were derived from the "magmatic" model (granitic composition of the melt, $\mathrm{T}=700-900^{\circ} \mathrm{C}, \mathrm{F}>\mathrm{Cl}$ in water-fluid composition) may be summarized in applicable average $K^{F / L}$ values and then recommended for further modelling. The representative examples of such experimental research were reported by (Chevichelov and Epelbaum, 1985) and other investigators.

According to "magmatic" model, major elements concentrations in residual melt within the whole $f$ values range is described as $C$ vs. $f$ polynomial equations

(Table 4, Fig. 8, c). So the experimentally determined $K^{F / L}$ average values allow calculating the non-inversion type elements content in fluid at any $f<f_{i n}$ values using the same expression (8). However, proposed procedure yields lesser accuracy of the $C^{F}$ evaluations due to inconstancy of real $K^{F / L}$ values in natural systems in contrast to the assumed constant ones.
6.4. Estimation of the model trace element content in hypothetical altered rocks

Metasomatically altered rocks spatially and genetically associated with granitoids commonly represent the product of complicated process of multistage interaction between the fluid (hydrothermal solution) and various host rocks. Such processes are usually controlled by multiple natural factors, only main of which can be taken into account in any geochemical model. Therefore, the modelling of the simplified and idealized variant of alteration process must be carried out.

The variant suggested in this work implies the monotone fluid (solution) temperature decrease as well as its coeval chemical composition changes caused by (1) equilibrium components exchange between fluid and host rocks and (2) precipitation of components as consequence of their solubility decrease during fast cooling of the solution. Mechanisms (1) and (2) were accepted as the main ways for metasomatites of the highest and the lowest temperature types formation respectively. These two extreme cases of idealized alteration processes may be modeled on a basis of following assumptions:

(1) The highest temperature type metasomatites. Melt temperature (estimated as Tmodel) at corresponding $f$ - parameter values is a realistic extreme (maximum) estimation for the temperature of such model metasomatites formation. Only rock-forming minerals take part in equilibrium components exchange between fluid and solid phases (own trace elements minerals crystallization is prohibited). Therefore, empirically assessed mineral $/ \mathrm{melt}$ distribution coefficient values for low-temperature rare metal granitoids (for example reported by (Antipin et al., 1984 etc.) are used for trace element solid/fluid bulk distribution coefficients $(D)$ calculation from expression (3). The rockforming minerals content in the earliest stages real metasomatites of natural metasomatic process were accepted as proportion of minerals in solid phase. Each trace element content in metasomatites $\left(C^{M S T}\right)$, which corresponds to fluid separated within the $f<f_{i n v}$ range, can be evaluated using the following simple expression:

$$
C^{M S T}=D \cdot C^{F} \text {. }
$$

(2) The lowest temperature type metasomatites. Minimum value among the thermometric results empirically obtained for the latest stages of natural metasomatic process is accepted as a temperature of such model metasomatites formation. Assumption that this hypothetical event resulted in complete precipitation of elements that were extracted from the melt is valid for model calculations. In this case each trace element content in metasomatites $\left(C^{M S T}\right)$, which corresponds to fluid separated within the $f<f_{\text {inv }}$ range, can be estimated as:

$$
C^{M S T}(\mathrm{ppm})=10^{6} \mathrm{C}^{F} / \Sigma_{C},
$$

where $\Sigma_{C}$ is the total element content in the fluid (including major elements and excluding $\mathrm{F}$ and $\mathrm{Cl}$ ) estimated via equation (8)

We must emphasize that model results, which were obtained using expressions (9) and (10), represent only the idealized extreme cases of altered rocks formation. Empirical data on the natural metasomatites can be compared to them exclusively on the main alteration trends level.

\section{Results and discussion}

Described procedure was applied to ore-bearing metasomatites trace element composition modelling. Initial data for all the calculations [ $D, D^{\prime}, C_{0}$ values for trace and polynomial equations for selected major elements (Table 4), final $f_{\text {inv }}$ value (0.123), Tmodel vs. $f$ equation (Fig. 10, d) 
etc.] were derived from the "magmatic" model of the Korosten pluton granitoids formation. Results of the modelling were compared to geochemical data set on natural metasomatically-altered rocks of the Perga area $(\S 4,5$; Tables $1-3)$ to verify the hypothesis on their genetic correlation with Korosten pluton granitoids.
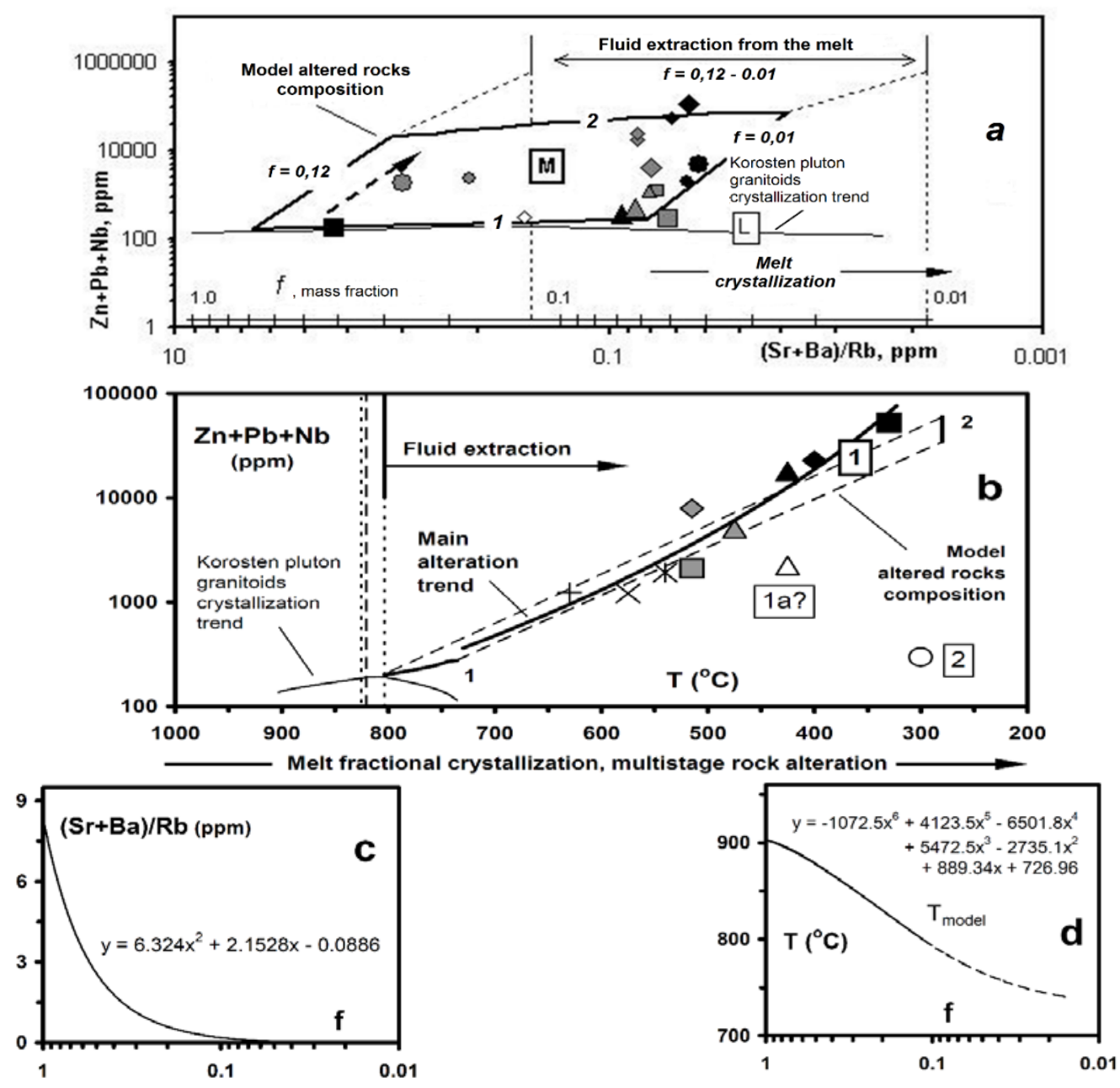

Fig. 10. Selected ore elements $(\mathrm{Zn}+\mathrm{Pb}+\mathrm{Nb})$ model content in hypothetical metasomatites produced

by aqueous fluid and average compositions of the real Perga area altered rocks plotted against ( $\mathrm{Sr}+\mathrm{Ba}) / \mathrm{Rb}$ (black symbols stand for monazite-bearing rocks; big and small symbols - data on bulk samples and average metasomatites compositions,

respectively; 1 and 2 - model range of concentration changes in high- and low-termperature metasomatites, respectively and $\mathrm{T}\left({ }^{\circ} \mathrm{C}\right)(\mathrm{b})$. Model $f$ values for magmatic system were recalculated in $(\mathrm{Sr}+\mathrm{Ba}) / \mathrm{Rb}$ and $\mathrm{T}$ values by the means of corresponding equations (c, d). See text for additional explanations

$K^{F / L}$ values for elements with inversion type of behavior $(\mathrm{F}, \mathrm{Cl}, \mathrm{Zn}, \mathrm{Pb}, \mathrm{Nb})$ within the $f<f_{i n v}$ range covered by the "magmatic" model ( $f=0.123-0.01$ ) were calculated from expression (7) using the equation (1) and data $\left(D, D^{\prime}, \mathrm{C}_{0}\right.$ values etc.) from Table 4. As it can be seen on Fig. 9a results calculated generally concur with the experimental results (Kovalenko, 1979; Chevichelov and Epelbaum, 1985 etc.) obtained for similar conditions. Noticeable but not significant difference was recorded only for the $F$ (calculated results are slightly higher than experimental estimations). This minor disagreement can be explained by some errors of the "magmatic" model. For example, not original, but reference data on $\mathrm{F}$ content in rocks were used in contrast to other elements during this model preparation (Shnyukov, 2001; Shnyukov, 2002; Shnyukov and Lazareva, 2002 etc.). Such feature of the initial whole-rock analytical data set may result in errors of estimation of both corresponding trend parameters $\left(D, D^{\prime}, \mathrm{C}_{0}\right.$ etc.) and $K^{F / L}$ values. And, of course, discrepancy noticed can be also caused by inaccuracy of the experimental results (Kovalenko, 1979; Chevichelov and Epelbaum, 1985 etc.). In general, the conducted comparison (Fig. 9, a) indicates sufficient reliability of model $K^{F / L}$ values calculated for elements with inversion type of behavior. For the most important major elements, following $K^{F / L}$ average values, based on experimental determinations (Chevichelov and Epelbaum, 1985 etc.), were accepted: Si (0.007), Al (0.0003), $\mathrm{Ca}(0.002), \mathrm{Na}(0.004), \mathrm{K}(0.001)$, $\mathrm{Fe}(0.0008)$.

Concentrations of $\mathrm{F}, \mathrm{Cl}, \mathrm{Zn}, \mathrm{Pb}, \mathrm{Nb}, \mathrm{Si}, \mathrm{Al}, \mathrm{Ca}, \mathrm{Na}, \mathrm{K}, \mathrm{Fe}$ in the fluid within the $f<f_{\text {inv. }}$ range covered by the "magmatic" model ( $f=0.123-0.01$ ) were calculated using expression (8), (1) and data from Table 4. Corresponding model element concentrations in metasomaticaly altered rocks were calculated from expressions (9) and (10). Solid/fluid bulk distribution coefficients $(D)$ for calculations on expression (9) were obtained from expression (3) on the basis of rock-forming mineral distribution coefficients empirical data (Antipin et al., 1984 etc.). At that, the rockforming minerals compositions in metasomatic granites of Perga type (Table 1) were accepted as minerals proportion in solid phase. Obtained $D$ values $\left(D_{\mathrm{Zn}}=1.47, D_{\mathrm{Pb}}=0.85\right.$, $D_{\mathrm{Nb}}=0.05$ etc.) substantially differ from the values derived from "magmatic" model (Fig. 9, c). 
Calculated model $\mathrm{Zn}, \mathrm{Pb}$ and $\mathrm{Nb}$ concentrations after their summation were plotted against $(\mathrm{Sr}+\mathrm{Ba}) / \mathrm{Rb}$ ratio and $\mathrm{T}\left({ }^{\circ} \mathrm{C}\right)$ on Fig. 10 , and 10 ? b. It makes it possible to combine magmatic and metasomatic components of the model on one plot [model $f$ values for "magmatic" model were recalculated in $(\mathrm{Sr}+\mathrm{Ba}) / \mathrm{Rb}$ and $\mathrm{T},{ }^{\circ} \mathrm{C}$ values by means of corresponding equations represented in Fig. 10, $\mathrm{c}$ and 10. d; values, similar to those derived from "magmatic" model for the same $f$, were accepted for $(\mathrm{Sr}+\mathrm{Ba}) / \mathrm{Rb}$ ratio in the model metasomatites composition]. The model area of altered rocks composition is restricted by curves 1 and 2 (Fig. 10, a and 10, b), which corresponds to the hypothetical (model) metasomatites of the highest and lowest temperature types respectively [§ 6.4, expressions (9) and (10)]. Real average compositions of investigated natural metasomatites of Perga area (Table 3 ) were plotted on the same diagrams to compare to the calculated (model) results. To do that, in the case of Fig. 10, b average temperature estimations on formation of each metasomatic variety were summarized basing on the reference data on temperature evaluations with fluid inclusions investigation methods (Bespalko, 1975; Vynar and Razumeeva, 1972; Gurov et al., 1971; Lazareva, 2015; Shatskaya and Shpanov, 1977; Shnyukov and Lazareva, 2002 etc.). Minimum empirical temperature values $\left(275^{\circ} \mathrm{C}\right)$ were accepted as a temperature of model the lowest temperature type metasomatites formation (curve 2).

Comparison represented in Fig. 10 shows that all the points with compositions corresponding to the natural metasomatites of the main $\left(1^{\text {st }}\right)$ alteration type were plotted within or close to the model area of altered rocks composition. Only the rarest metasomatic varieties of $1 \mathrm{a}$ and $2^{\text {nd }}$ alteration type did not correspond to the compositions calculated. The results stated above prove the existence of genetic correlations between granitoids of the Korosten pluton and altered varieties (metasomatites) of Perga area with economic ore mineralization.

\section{Conclusions}

(1) Good agreement between calculated model results and analytical results on main types of natural metasomatites composition ensure genetic correlation between ore-bearing metasomatites of Perga area and Korosten pluton granitoids. Results obtained may be considered an example of geochemical modeling ability for assessment of high-temperature metal-bearing fluids that account for both metasomatic alteration and ore mineralization processes source.

(2) Realistic estimations for a number of important parameters $\left(K^{F / L}, C^{F}, f_{i n v}\right.$., fluid/melt ratio and weight fraction of fluid phase in the whole system for each $f<f_{i n v}$ value etc.) were derived from combination of the "magmatic" and "metasomatic" models designed. New data are valid for real natural ore-forming system and provide additional opportunity, as compared to the earlier research results (Ryabchikov, 1975; Ryabchikov, 1976; Shnyukov and Lazareva, 2002 etc.), on the basis of general evaluations of these parameters, to grant more precise estimations of the amounts of ore elements extracted by the fluid from the melt during the granitoid pluton formation.

(3) Described technique enables to model genetic evolution of ore deposits in hydrothermally altered rocks as well as to produce the reliable estimations of potential orebearing potential of different granitoid complexes. Therefore, it may be used as a powerful tool for area selection and target evaluation in hydrothermallymetasomatic ore deposits exploration.

\section{Acknowledgements}

This work was supported by the Scientific Research Department of the Taras Shevchenko National University of Kiev throughout grants 0195U004122, 0195U004123, 0197U003159 and 0116U004784. Important samples for geochemical data set formation were contributed by A.I. Belous and E.A. Khlon with the aid of E.L. Docenko. The authors give their thanks to O.V. Zinchenko, for numerous consultations as well as to A.V. Andreev and V.V. Zagorodny for the significant assistance in analytical investigations.

\section{Список використаних джерел}

1. Антипин, В.С., Коваленко, В.И., Рябчиков, И.Д. (1984). Коэффициенты распределения редких элементов в магматических породах. Монография. Москва: Наука.

2. Беспалько, Н.А. (1975). Формации Сущано-Пержанской зоны. Критерии прогнозирования месторождений Украинского щита и его обрамления. Киев: Наук. думка,135-137.

3. Білоус, О.І. (1994). Високотемпературні метасоматичні формації Сущано-Пержанської зони Українського щита та їх рудоконтролююче значення. Автореф. дис. ... канд. геол.-мінерал. наук: 23.06.94. Київ.

4. Великославинский, Д.А., Биркис, А.П., Богатиков, О.А., Бухарев, В.П., Великославинский, С.Д., Гордиенко, Л.Д., Зинченко, О.В., Кивисилла, Я.Я., Кирс, Ю.Е., Кононов, Ю.В., Левицкий, Ю.Ф., Ниин, М.И., Пуура, В.А., Хворов, М.И., Шустова, Л.Е. (1978). Анортозит-рапакивигранитная формация Восточно-Европейской платформы. Монография. Ленинград: Наука.

5. Верхогляд, В.М. (1995). Возрастные этапы магматизма Коростенского ппутона. Геохимия и рудообразование, 21, 34-47.

6. Вынар, О.Н., Разумеева, Н.Н. (1972). Особенности образования гидротермальной минерализации Сущано-Пержанской зоны. Минералогич. сб. Львовск. ун-та, 2, 26, 197-206.

7. Галецький, Л.С., Зинченко, О.В. (1971). Досвід застосування геохімічних досліджень для вирішення різних геологічних завдань. Геологічний журнал, 31, 1, 11-19.

8. Галецкий, Л.С. (1974). Миграция вещества при образовании метасоматитов северо-западной части Украинского щита. Геол. журнал, 34, 2, 24-35.

9. Гуров, Є.П., Марченко, Є.Я., Металіді, С.В. (1971). До умов утворення фенакіту в апогранітових метасоматитах. Доп. АН УРСР, Б, 5, 391-394.

10. Есипчук, К.Е., Орса, В.И., Щербаков, И.Б., Шеремет, Е.М., Скобеев, В.М., Рябоконь, В.В., Галецкий, Л.С., Панов, В.С., Юшин, А.А., Бочай, Л.В., Голуб, Е.Н., Демьяненко, В.В., Бучинская, К.М., Свечников, К.И., Сухоруков, Ю.Т., Щербак, Д.Н., Осадчий, В.К., Пийяр, Ю.К., Самчук, А.И., Кушнир, А.С., Андреев, А.В., Чебуркин, А.К. (1993). Гранитоиды Украинского щита: петрохимия, геохимия, рудоносность. Справочник. Киев: Наук. думка.

11. Казицин, Ю.В., Рудник, В.А. (1968). Руководство к рассчету баланса вещества и внутренней энергии при формиированиии метасоматиических пород. Москва: Недра, 105-115.

12. Коваленко, Н.И. (1979). Экспериментальное исследование образования редкометальных литий-фтористых гранитов. Монография. Москва: Наука.

13. Лазарєва, І.І. (2015). Геохімія та забарвлення природних фрлюоритів: ефективність і простота застосування в практиці мінералого-геохімічних досліджень. Вісник Київського національного університету. Геологія, 68, 32-39.

14. Лазарєва, І.І. (2015). Інформативність типізації цирконів з метасоматитів за деякими фізичними, морфологічними та геохімічними ознаками. Вісник Київського національного університету. Геологія, 69, 24-29.

15. Металиди, С.В., Нечаев, С.В. (1983). Сущано-Пержанская зона (геология, минералогия, рудоносность): Монография. Киев: Наук. думка.

16. Митрохин, О.В. (2008). Петрографічний склад комплексів анортозит-рапаківігранітної формації. Вісник Київського національного університету. Геологія, 45, 62-66.

17. Нечаев, С.В. (1998). Металлогения раннего докембрия и рифеяпротерозоя Украинского щита. Мінералогічний журнал, 20, 88-99.

18. Пономаренко, А.Н., Степанюк, Л.М., Шумлянский, Л.В. (2014). Геохронология и геодинамика палеопротерозоя Украинского щита. Мінерапогічний журнал, 36, 2, 48-60.

19. Рябчиков, И.Д. (1975). Термодинамика флюидной фазы гранитоидных магм. Монография. Москва: Наука.

20. Рябчиков, И.Д. (1976). Физико-химические аспекты связи эндогенного рудообразования с магматизмом. Магматизм и эндогенное рудообразование. Москва: Наука, 13-22.

21. Чевычелов, В.Ю., Эпельбаум, М.Б. (1985). Распределение Pb, Zn и петрогенных компонентов в системе гранитный расплав-флюид. В кH. Очерки физико-химической петрологии (экспериментальное исследование проблем магматизма). Москва: Наука, 120-135.

22. Шацкая, В.Т., Шпанов, Е.П. (1977). Особенности формирования берилиевого оруденения, связанного с полевошпатовыми метасоматитами зон активизации древних щитов. Закономерности формирования гидротермальных месторождений берилия. Москва: Недра, 192-215.

23. Шеремет, Е.М., Кулик, С.Н., Кривдик, С.Г. и др. (2011). Геолого-геофизические критерии рудоносности и металлогения областей субдукции Украинского щита. Донецк: Ноулидж. 
24. Шеремет, Е.М., Кривдик, С.Г., Седова, Е.В. (2014). Редкометальные граниты Украинского щита (петрология, геохимия, геофизика и рудоносность). Донецк: Ноулидж.

25. Шнюков, С.Є. (2001). Наскрізні акцесорні мінерали в геохімічному моделюванні магматичних процесів. Збірник наукових праць УкрДГРІ, 1-2, 41-53.

26. Шнюков, С.Е. (2002). Геохимические модели эволюции магматических систем и земной коры: потенциальный источник петрофизической и рудогенетической информации. Геофизический журнал, 24, 6, 201-219.

27. Шнюков, С.Є., Лазарєва, І.І. (2002). Геохімічне моделювання в дослідженні генетичного зв'язку магматичних комплексів та просторово асоціюючих з ними гідротермально-метасоматичних рудних родовищ. Збірник наукових праць УкрДГРІ, 1, 128-143.

28. Щербаков, И. (2005) Петрология Украинского щита. Львов: ЗУКЦ 29. Gavryliv, L., Shnyukov, S., Lazareva, I. (2016). Geochemical behavior of major and trace elements during magma evolution process in Bodie Hills Volcanic Field, Nevada. Geoinformatics-. XV-th International Conference on Geoinformatocs. Theoretical and Applied Aspects (May 10-13, 2016, Kiev, Ukraine). $\mathrm{http}: / / \mathrm{ww}$.earthdoc.org/publication/publicationdetails/ ?publication=84616

30. Harrison, T.M. Watson, E.B. (1984). The behavior of apatite during crustal anatexis: Equilibrium and kinetic considerations. Geochim. et Cosmochim., 48, 1467-1477.

31. Lazareva, I., Shnyukov, S., Hlon, E., Aleksieienko, A., Morozenko, V., Gavryliv, L. (2017). Volcanoes of Antarctica as object of geological and ecological research at an example of Deception Island. Materials of XI Unternational Scientific Conference "Monitoring of Geological Processes and Ecological Condition of the Enviroment" (October 11-14, 2017, Kyiv, Ukraine).

32. Montel, J.M. (1993). A model for monazite/melt equilibrium and application to the generation of granitic magmas. Chemical Geology, 110, 127-145

33. Neumann, H., Mead, J., Vitaliano, C.J. (1954). Trace element variation during fractional crystallisation as calculated from the distribution law. GCA, 6, 90-99.

34. Shnyukov, S.E., Andreev, A.V., Zinchenko, O.V., Khlon, E.A., Lazareva, I.I., Zagorodny, V.V., Grinchenko, A.V. (2000).' Geochemical modelling of Pre-Cambrian granitoid evolution in Ukrainian Shield: petrogenetic aspects and genesis of complex rare metal, polymetalic and gold mineralization in neighbouring metasomatic zones (Korosten anorthositerapakivigranite pluton as an example). Abstract volume \& Field trip guidebook, 2nd annual GEODE-Fennoscandian Shield workshop on Palaeoproterozoic and Archaean greenstone belts and VMS districts in the Fennoscandian Shield (28 August - 1 September, 2000, Gallivare-Kiruna, Sweden). Lulea University of Technology, Research Report 2000, 6, 37-40.

35. Shnyukov, S., Lazareva, I., Zinchenko, O., Khlon, E., Gavryliv, L., Aleksieienko, A. (2018). Geochemical model of precambrian granitoid magmatic evolution in the Korosten Pluton (Ukrainian Shield): petrogenetic aspects and genesis of complex ore mineralization in metasomatic zones. Вісник Київського національного університету. Геологія, 81.

36. Watson, E.B., Harrison, T.M. (1983). Zircon saturation revisited: temperature and composition effects in a variety of crustal magma types. Earth and Planetary Science Letters, 64, 295-304.

\section{References}

1. Antipin, V.S., Kovalenko, V.I., Ryabchikov, I.D. (1984). Distribution coefficients of rare elements in magmatic rocks. Nauka Press, Moscow. [in Russian]

2. Bespalko, N.A (1975). Metasomatites of the Suschano-Perga belt. In Criteria on the deposites prospecting within the Ukrainian Shield region. Kiev: Naukova dumka Press, 225-230. [in Russian]

3. Belous, A.I. (1994). High-temperature metasomatic formations of Suschano-Perga area and their significance as a control factor for ore localization. Extended abstract of Candidate's thesis (Geol.-Min. Sciences). Institute of Geochemistry, Mineralogy and Ore Formation of the Ukrainian Academy of Sciences, Kiyv. [in Russian]

4. Chevichelov, V.Y., Epelbaum, M.B. (1985). Lead, zinc and major element distribution in granite melt-fluid system. In: Physico-chemical petrology. Moscow: Nauka Press, 120-135. [in Russian]

5. Esipchuk, K.E., Orsa, V.I., Scherbakov, I.B., Sheremet, E.M., Skobelev, V.M., Ryabokon, V.V., Galitsky, L.S., Panov, B.S., Yushin, A.A., Bochay, L.V., Golub, E.N., Demyanenko, V.V., Buchinskaya, K.M., Sveshnikov, K.I., Sukhorukov, Yu.T., Scherbak, D.N., Osadchy, V.K. Piya, Yu.K., Samchuk, A.I., Kushnir, A.S., Andreev, A.V., Cheburkin, A.K. (1993). Granitoids of the Ukrainian Shield: petrochemistry, geochemistry and ore deposites (reference book). Kiev: Naukova dumka Press. [in Russian]

6. Galetsky, L.S., Zinchenko, O.V. (1971). Experience on the geochemical research application to the various geological problems solution. Geological Journal, 1, 31, 11-19. [in Russian]

7. Galetsky, L.S. (1974). Mass balance during the metasomatites of the north-western part of the Ukrainian Shield. Geological journal, 2, 34, 24-35. [in Russian]

8. Gavryliv, L., Shnyukov, S., Lazareva, I. (2016). Geochemical behavior of major and trace elements during magma evolution process in Bodie Hills Volcanic Field, Nevada. XV-th International Conference on Geoinformatocs, Theoretical and Applied Aspects (May 10-13, 2016, Kiev, Ukraine). http://www.earthdoc.org/publication/publicationdetails/?publication=84616

9. Gurov, E.P., Marchenko, E.Y., Metalidi, S.V. (1971). To the conditional features of phenakite formation in apogranite metasomatites. Papers of AS of the USSR, Ser. B, 5, 391-394. [in Russian]

10. Harrison, T.M., Watson, E.B. (1984). The behavior of apatite during crustal anatexis: Equilibrium and kinetic considerations. Geochim. et Cosmochim, Acta 48, 1467-1477.
11. Kazitsyn, Yu.V, Rudnik, V.A. (1968). Manual on the calculation of mass balance and internal energy during the metasomatic rocks formation. Moscow: Nedra Press, 105-115. [in Russian]

12. Kovalenko, N.I. (1979). Experimental investigations on raremetal litium-fluoric granites. Moscow: Nauka Press. [in Russian]

13. Lazareva, I.I. (2015). Geochemistry and color of natural fluorites: efficiency and simplicity of practical application in mineralogic and geochemical research. Visnyk of Taras Shevchenko National University of Kyiv. Geology, 68, 32-39. [In Ukrainian].

14. Lazareva, I.I. (2015). Informational content of metasomatic zircons typing by everal physical, morphologic and geochemical features. Visnyk of Taras Shevchenko National University of Kyiv. Geology, 69, 24-29. [In Ukrainian]

15. Lazareva, I., Shnyukov, S., Hlon, E., Aleksieienko, A., Morozenko, V., Gavryliv, L. (2017). Volcanoes of Antarctica as object of geological and ecological research at an example of Deception Island. Materials of XI Unternational Scientific Conference "Monitoring of Geological Processes and Ecological Condition of the Enviroment" (October 11-14, 2017, Kyiv, Ukraine).

16. Metalidi, S.V., Nechaev, S.V. (1983). Suschano-Perga area (geology, mineralogy and ore deposits). Kiev: Naukova dumka Press. [in Russian]

17. Montel, J.M. (1993). A model for monazite/melt equilibrium and application to the generation of granitic magmas. Chemical Geology, 110, 127-145

18. Mytrohyn, O.V. (2008). Anorthosite-rapakivi-granite association complexes petrographic composition. Visnyk of Taras Shevchenko National University of Kyiv. Geology, 45, 62-66. [in Ukrainian]

19. Neumann, H., Mead, J., Vitaliano, C.J. (1954). Trace element variation during fractional crystallisation as calculated from the distribution law. GCA, 6, 90-99.

20. Nechaev, S.V. (1998). Early Precambrian and Riphean-Phanerozoic metallogeny of the Ukrainian Shield. Mineralogical Journal, 20, 88-99. [in Russian]

21. Ponomarenko, A.N., Stepanuyk, L.M., Shumlyanskiy, L.V. (2014). Geochronology and geodynamics fof Paleoproterozoic Ukrainian Shield. Mineralogical journal, 36, 2, 48-60. [in Russian]

22. Ryabchikov, I.D. (1975). Thermodynamics of the fluid phase in granitoid magmas. Moscow: Nauka Press. [in Russian]

23. Ryabchikov, I.D. (1976). Physicochemical aspects of endogenetic ore formation and magmatic processes. In: Magmatism and endogenetic ore formation. Moscow: Nauka Press, 13-22. [in Russian]

24. Shatskaya, V.T., Shpanov, E.P. (1977). Peculiaritis of berrilium ore formations associated with feldspaar metasomatites of activisation zone within ancient shields. In: Regularities in formation of hydrothermal berrilium deposits. Moscow: Nadra Press, 192-215. [in Russian]

25. Sheremet, E.M., Kulik, S.N., Krivdik, S.G., et al. (2011) Geologicalgeophysical criteria of ore-bearing and mineral resources of subduction areas of Ukrainian Shield. Donetsk: "Knowledge". [in Russian]

26. Sheremet, E.M., Krivdik, S.G., Sedova, E.V. (2014) Rare metal granites of Ukrainian Shield (petrology, geochemistry, geophysics and minerals). Donetsk: "Knowledge". [in Russian]

27. Sherbakov, I. (2005) Petrology of Ukrainian Shield. Lviv: ZUKC. [in Russian]

28. Shnyukov, S.E. (2001). Ubiquitous accessory minerals in geochemica modeling of magmatic processes. Zbirnuk naukovih materialiv UkrDGRI, 1-2, 41-53. [In Ukrainian]

29. Shnyukov, S.E. (2002). Geochemical models of magmatic systems and earth's crust evolution: potential source of petrophysical and oregenetical information. Geophysical journal, 24 (6), 201-219. [in Russian]

30. Shnyukov, S.E., Lazareva, I.I. (2002). Geochemical modeling in research of genetic connection of magmatic complexes and spatially associated hydrothermal-metaspmatic ore deposits. Zbirnuk naukovih prac UkrDGRI, 1, 128-143. [In Ukrainian]

31. Shnyukov, S.E., Andreev, A.V., Zinchenko, O.V., Khlon, E.A. Lazareva, I.I., Zagorodny, V.V., Grinchenko, A.V. (2000).' Geochemical modelling of Pre-Cambrian granitoid evolution in Ukrainian Shield: petrogenetic aspects and genesis of complex rare metal, polymetalic and gold mineralization in neighbouring metasomatic zones (Korosten anorthosite-rapakivigranite pluton as an example). In Weihed, P., Martinsson, O. (Eds.) Abstract volume \& Field trip guidebook, 2nd annual GEODE-Fennoscandian Shield workshop on Palaeoproterozoic and Archaean greenstone belts and VMS districts in the Fennoscandian Shield (28 August - 1 September, 2000, Gallivare-Kiruna, Sweden). Lulea University of Technology, Research Report 2000:6, 37-40.

32. Shnyukov, S., Lazareva, I., Zinchenko, O., Khlon, E., Gavryliv, L., Aleksieienko, A. (2018). Geochemical model of precambrian granitoid magmatic evolution in the Korosten Pluton (Ukrainian Shield): petrogenetic aspects and genesis of complex ore mineralization in metasomatic zones. Visnyk KNU. Geology, 81

33. Velikoslavinsky, D.A., Birkis, A.P., Bogatikov, O.A., Bukharev, V.P., Velikoslavinsky, S.D., $\quad$ Gordienko, L.I., Zinchenko, O.V., Kivisilla, Ya.Ya. Kirs, Yu.E., Kononov, Yu.V., Levitsky, Yu.F., Niin, M.I., Puura, V.A., Khvorov, M.I., Shustova, L.E. (1978). The anorthosite-rapakivi granite formation of the East European platform. Leningrad: Nauka Press. [in Russian]

34. Verchogliad, V.M. (1995). Age stages of magmatic processes of the Korosten pluton. Geochemistry and ore formation, 21, 34-47. [in Russian]

35. Vynar, O.N., Razumeeva, N.N. (1972). Some formational features of hydrothermal mineralisation of Suschano-Perga zone. Mineralogical Journal, 26, 2, 197-206. [in Russian]

36. Watson, E.B., Harrison, T.M. (1983). Zircon saturation revisited: emperature and composition effects in a variety of crustal magma types. Earth and Planetary Science Letters, 64, 295-304

Надійшла до редколегії 31.03.18 
І. Лазарєва, канд. геол. наук, доц.,

E-mail: lazareva@mail.univ.kiev.ua,

С. Шнюков, д-р геол. наук, доц.,

E-mail: shnyukov@mail.univ.kiev.ua,

А. Алексєєнко, асп.,

E-mail: scr315@gmail.com,

л. Гаврилів, асп.,

E-mail: liubomyr.gavryliv@gmail.com

Київський національний університет імені Тараса Шевченка

НHI "Інститут геології", вул. Васильківська, 90, м. Київ, 03022, Україна

\section{РУДОНОСНІ МЕТАСОМАТИТИ СУЩАНО-ПЕРЖАНСЬКОЇ ЗОНИ І ГРАНІТОЇДИ КОРОСТЕНСЬКОГО ПЛУТОНУ (УКРАЇНСЬКИЙ ЩИТ): ГЕНЕТИЧНІ ВІДНОСИНИ ЗА ДАНИМИ ГЕОХІМІЧНОГО МОДЕЛЮВАННЯ}

У роботі представлено результати детального вивчення геохімії процесу формування рудоносних метасоматитів Сущано-Пержанської зони, що просторово асоціює з докембрійським (1,75-1,8 млрд років) Коростенським анортозит-рапаківігранітним плутоном. Досліджена поведінка головних і мікроелементів у процесі багатостадійного змінення вмісних порід (переважно гранітів). Виділено декілька типів геохімічних змін, у результаті яких були сформовані відповідні метасоматumu: (1) $\mathrm{Fe}-\mathrm{Mg}-\mathrm{Na}-\mathrm{K}-\mathrm{Zn}, \mathrm{Pb}, \mathrm{Nb}, \mathrm{Rb}, \mathrm{Cs}, \mathrm{Cd}(\mathrm{Be}, \mathrm{Li}, \mathrm{Ta} u$ m. д.) - апограніти, альбітити-І, альбіт-мікроклин, мікроклин-альбіт, сидерофіліт-калішпат і сидерофілітові метасоматити; (1a) NaNb, Sn (Ta, Be u m. д.) - альбітumu-Il; (2) Si-(Sn, Be, W u m. д.) - апограніти і кварц-мусковітові грейзени. Метасоматити периого (головного) типу є найпоширенішими і містять більшу частину рудної мінералізації. Одержані геохімічні дані були зіставлені з гіпотетичними композиціями метасоматитів, які розраховані виходячи з геохімічної моделі формування гранітоїдів Коростенського плутону, у якій використане фракціонування Релея і рівняння розчинності циркону, апатиту та монациту в силікатних розплавах для оцінки температури кристалізації гранітної магми і вмісту в ній $\mathrm{H}_{2} \mathrm{O}$. Одержані 3 моделі залежності $\mathrm{C}^{L}=\mathrm{C}_{0} \mathrm{f}^{\mathrm{D}} 1\left(\mathrm{C}_{0}-\right.$ вміст елемента у вихідному розплаві, $C^{L}$ - вміст елемента у залишковому розплавi, $f$ - масова частка рідкої фази в глибинній магматичній камері, $D$ - комбінований коефіцієнт розподілу елемента) для $\mathrm{Zn}, \mathrm{Pb}, \mathrm{Nb}, \mathrm{F}$ i Cl мають інверсійний характер. Їхні інверсійні перегини збігаються за значенням $\mathrm{f}$ з моментом досягнення залишковим розплавом концентрації насичення $\mathrm{H}_{2} \mathrm{O}$ і відокремленням водного флюїду. Відповідні рівняння демонструють різку зміну $D$ в момент інверсії, що дозволило розрахувати значення $K^{F / L}=C^{F} / C^{L}\left(C^{F}\right.$ - вміст елемента у фолюїді) $i$ оцінити концентрації Zn, $\mathrm{Pb}, \mathrm{Nb}$ в гіпотетичних (модельних) метасоматитах. Модельні концентрації елементів добре узгоджуються зі складом реальних рудоносних метасоматитів Сущано-Пержанської зони, що підтверджує можливість їх формування високотемпературними рудоносними флюїдами, які були генеровані в результаті магматичної еволюції гранітоїдів Коростенського плутону.

Ключові слова: метасоматити, граніти, мікроелементи, магматична еволюція, відокремлення флюїду, коефіцієнт розподілу флюїд/розплав, змінення гірських порід, рудна мінералізація.

И. Лазарева, канд. геол. наук, доц.

E-mail: lazareva@mail.univ.kiev.ua,

С. Шнюков, д-р геол. наук, доц.,

E-mail: shnyukov@mail.univ.kiev.ua,

А. Алексеенко, асп.,

E-mail: scr315@gmail.com,

Л. Гаврылив, асп.,

E-mail: liubomyr.gavryliv@gmail.com

Киевский национальный университет имени Тараса Шевченко

УнИ "Институт геологии", ул. Васильковская 90, г. Киев, 03022, Украина

\section{РУДОНОСНЫЕ МЕТАСОМАТИТЫ СУЩАНО-ПЕРЖАНСКОЙ ЗОНЫ \\ И ГРАНИТОИДЫ КОРОСТЕНСКОГО ПЛУТОНА (УКРАИНСКИЙ ЩИТ): ГЕНЕТИЧЕСКИЕ ВЗАИМООТНОШЕНИЯ ПО ДАННЫМ ГЕОХИМИЧЕСКОГО МОДЕЛИРОВАНИЯ}

В работе представлены результаты детального изучения геохимии процесса формирования рудоносных метасоматитов СущаноПержанской зоны, пространственно сопряженной с докембрийским (1,75-1,8 млрд лет) Коростенским анортозит-рапакивигранитным плутоном. Исследовано поведение главных и микроэлементов в процессе многостадийного изменения вмещающих пород (преимущественно гранитов). Выделено несколько типов геохимических изменений, в результате которых были сформированы соответствующие метасоматиты: (1) $\mathrm{Fe}-\mathrm{Mg}-\mathrm{Na}-\mathrm{K}-\mathrm{Zn}, \mathrm{Pb}, \mathrm{Nb}, \mathrm{Rb}, \mathrm{Cs}, \mathrm{Cd}(\mathrm{Be}, \mathrm{Li}, \mathrm{Ta}$ u m. .) - апограниты, альбититы-I, альбит-микроклин, микроклин-альбит, сидерофиллит-калишпат и сидерофиллитовые метасоматиты; (1a) Na-Nb, Sn (Ta, Be u m. d.) - альбитuты-Il; (2) Si-(Sn, Be, W и m. d.) апограниты и кварц-мусковитовые грейзены. Метасоматиты первого (главного) типа наиболее широко распространены и вмещают большую часть рудной минерализации. Полученные геохимические данные были сопоставлены с гипотетическими составами метасоматитов, рассчитанными исходя из геохимической модели формирования гранитоидов Коростенского плутона, в которой использовано фракционирование Реллея и уравнения растворимости циркона, апатита и монацита в силикатных расплавах для оценки температуры

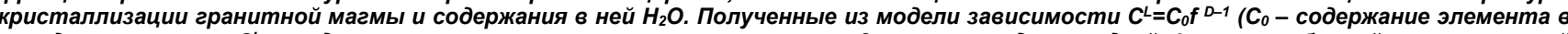
исходном расплаве, $C^{L}$ - содержание элемента в остаточном расплаве, $f$ - массовая доля жидкой фазы в глубинной магматической камере, $\mathrm{D}$ - комбинированный коэффициент распределения элемента) для $\mathrm{Zn}, \mathrm{Pb}, \mathrm{Nb}, \mathrm{F}$ и $\mathrm{Cl}$ носят инверсионный характер. Их инверсионные перегибы совпадают по значению $\mathrm{f} \mathrm{c} \mathrm{моментом} \mathrm{достижения} \mathrm{остаточным} \mathrm{расплавом} \mathrm{концентрации} \mathrm{насыщения} \mathrm{H}_{2} \mathrm{O}$ и отделением водного флюида. Соответствующие уравнения демонстрируют резкое изменение $D$ в точке инверсии, что позволило рассчитать значения $K^{F / L}=C^{F} / C^{L}$ ( $C^{F}$ - содержание элемента во флюuде) и оценить концентрации $\mathrm{Zn}, \mathrm{Pb}, \mathrm{Nb}$ в гипотетических (модельных) метасоматитах. Модельные концентрации элементов хорошо согласуются с составом реальных рудоносных метасоматитов Сущано-Пержанской зоны, что подтверждает возможность их формирования высокотемпературными рудоносными фолюидами, которые были генерированы в результате магматической эволюции гранитоидов Коростенского плутона.

Ключевые слова: метасоматиты, граниты, микроэлементы, магматичечкая эволюция, отделение флюида, коэффициент распределения флюид/расплав, изменения горных пород, рудная минерализация. 